\title{
Biblical Etymology of Relatives: Origin of Language
}

\author{
James Xianxing Du \\ Scholar, United States \\ Email: xx1du@yahoo.com
}

\author{
Article History \\ Received: 30 October, 2021 \\ Revised: 28 November, 2021 \\ Accepted: 24 December, 2021 \\ Published: 31 December, 2021 \\ Copyright (c) 2021 ARPG \& \\ Author \\ This work is licensed under the \\ Creative Commons Attribution \\ International \\ (c) () \\ CC BY: Creative \\ Commons Attribution License \\ 4.0
}

\begin{abstract}
Regarding origin of language, Genesis claims that ancient languages were divinely diversified. This testimony presents systematic evidence for biblical etymology related to relatives, solving word riddles on all relatives. Family is flame of altar, and relative is related to altar, because early relatives were worshipers around altar. Patriotism is parental worship, patriot is to cut in pair at altar, aunt is to count, offspring is off spring, descendant is related to census, blessing is related to sibling as brother, sister is to assist, woman is own, female is self in flesh, to marry is to Mary, to marry is to arrive, bride is related to tribe, Child is under cloud in addition to Infant's finance, nephew has new place or no female, and girl and ugly are not to offer with hand in unclean period. 息 breath has rest 息. 休 rest has tree 木. Testimony has stone $\square$ of ten commandments in tent $\Gamma$. This major discovery in civilization on multilingual mutual match to biblical etymology addresses fundamental semantic structure of words in relatives. This provides revolutionary method of learning vocabulary by bilingual mutual match to biblical etymology.
\end{abstract}

Keywords: Origin of language; Multilingual mutual match in biblical etymology; Relatives; Anthropology; Archaeology; Vocabulary.

\section{Introduction}

Genesis 11 (Moses, 2nd millennium B.C.a) claims that GOD "confused the language of the whole world" (Moses, 2nd millennium B.C.a), when languages suddenly burst out, so that people want to find linguistic evidence for such confusion and words' true etymology. Recently, divine creation of languages was systematically proven through multilingual mutual match in biblical etymology (Du, 2019a;2019b;2019c;2020a;2020b;2020c;2020d;2020e). Thus, ancient languages share identical source of etymological origin to extensively match bible.

The legendary claim that languages were divine gifts was known by ancient linguists such as Shen Xu 许慎, a major linguist in Han dynasty of China. For instance, the right structural affix of the word 祖 ancestor was 
interpreted to contain divine or memorial tablet, and the other affix 示 was interpreted as altar (Xu, 100-121 A.D.).

However, because of many misinterpretations from mainstream religions and false hypothesis of natural origin, numerous linguists hypothesized that initial words were created by humans rather than divinely, and thus intrinsic mutual connection among different languages in the common definitive biblical etymology was not presented until this set of testimonies. For example, linguists hypothesized that nose represents self because people pointed to their own nose when introducing each other (Liu, 2017), although its real etymology is Adam's nose of breath of life in Genesis 2:7 (Moses, 2nd millennium B.C.a). Linguists could be puzzled by why woman rather than man, and servant rather than officer, was in weapon of bow, and hypothesized that 驽 was created by borrowing 奴's sound. Correspondingly, most linguists hypothesized that languages were derived phonetically (DeFrancis, 1984). Many linguists even considered that Maya language was also primarily based on pronunciation, and had no intrinsic relationship with other language families (Campbell et al., 1986), although multiple Mayan words have been presented with bilingual biblical etymology ( $\mathrm{Du}, 2019 \mathrm{a} ; 2019 \mathrm{c})$. Thus, traditional hypothesis on linguistic origin that dominated the field in the last century has to be completely revised.

\section{Method}

Each word in an ancient language is a riddle, in other words, logogriph. Substructures of each word in the language of China are dissected to see how they form a meaningful word to match biblical events, decrees, worshipers and conversations in graphic and semantic organization. For each English word with biblical match, it is aligned with its translation in the current, traditional, seal and bone versions of the language of China and additional languages such as Latin and Greek, in order to mutually decode the etymology of a word. Linkage analysis is also performed to interconnect words together to match identical biblical origin in etymology. Divine creation of languages is shown by the following logic: Words match biblical events, decrees, worshipers and speech in etymology. It is impossible that words coincidentally match bible in such a large scale, indicating that they were purposely designed in advance to match biblical records. Thus, the creation is proven. Thus, THE CREATOR is proven.

In native and foreign vocabulary teaching, a teacher tells students etymological source of words as an interesting biblical story. Then, the teacher tells the students how substructures of the words are organized to match this biblical story. In foreign vocabulary learning, a teacher further tells students how a translation of a word in the students' native language also matches another language in biblical etymology. This dramatically improves faster understanding and deeper memory of the words.

\section{Results}

\subsection{Ancestor}

\subsubsection{Etymology of Ancestor}

This article proposes three biblical interpretations for ancestor 血且且柤示且祖. The first interpretation is fire $(\triangle, \triangle$ or $\square$ ) from the most ancient types of burnt altar built by overlaying stones $(\square, \square \square, \nabla \square$ or $\square \square$ ) on ground - In etymology, ancestry, ancestral and ancestor are to section and burn offering, and $\square \square$ can also be considered as sectioned offering, when can of candle, volcano and cannon is an affix to burn. The presence of a major root of divinity 示 "they took stones and put them in a pile" and "Jacob took an oath in THE NAME OF THE GOD his father Isaac worshiped. He offered a sacrifice there in the hill country", so that stony hill 砠 has an altar and sectioned meat. The altar could also be built by earth, as earth $土$ was initially written as $\boldsymbol{\Lambda}$ in bone version, and $\boldsymbol{\perp}$ in bronze version.

且且姐目且 means too, $\perp$ o o, 几 $口$, due to multiple stones and offerings. Its bone version was drawn 
in straight lines, since it was more difficult to carve curves on turtle and ox bones. 具 tool is for offering at altar. Too also means too much 甚是, which has burnt altar $\Theta$. With people to assist 助 in repairing an altar in 1 Kings 18:32-39 (Unknown author, 1st millennium B.C.a), "Elijah used the stones to build an altar in honor of THE LORD.” 沮 is utensil for sectioning meat. 咀 chew is to eat the offered portion as priest's share. 蛆 is worm grown in leftover meal. 龉 teeth of discord were avid for extra diet in Numbers 11:4-34 (Moses, 2nd millennium B.C.d). 炭疽 anthrax has 火 fire at altar 且, as burn offering at altar for purification from infection in Leviticus. 租 rent has 禾 grain or incense offering at altar. Priests tilt 趣 toward altar, wearing gems 珇. 㫿 osprey is a bird near altar. 米 grain at altar is thick 粗, but scarlet yarn 丝 to be burnt on altar's grating 田 is thin 細.

盈且目且柤祖祖 ancestor was interpreted as male's private part, although the second and more accurate interpretation is the circumcised part, reflecting biblical covenant and design of lexicon in high moral standard. In "the covenant you are to keep: Every male among you shall be circumcised. You are to undergo circumcision, and it will be the sign of the covenant" between GOD and Abraham, this ancestor of biblical nation and acknowledged earthly father of faith circumcised with flint knife as lancet. $\Delta \diamond \diamond$ are the exposed tip, $\mathbf{Z}=$ are the upper and lower edges of the remaining cover skin, and 一 is body surface. 示 is radiating (小) cloud (二, 云) merged with a marker of division 八, because GOD ascends and descends in cloud. "Abraham was ninety-nine years old when he was circumcised, and his son Ishmael was thirteen" in Genesis 17:23-21:4 (Moses, 2nd millennium B.C.a). When "Isaac was eight days old, Abraham circumcised him, as GOD commanded him". Covenant is to remove cover of the private part of man, and circumcision is to uncover, an cove native clan.

药 drug has covenant 约's $\subsetneq$, a line pointing to private part of worshiper' , and treats injury from circumcision. Related to purge because of purification after circumcision, drug is for foreskin to go away in agreement, or to go to the rural for quarantine of leprosy in Leviticus. As eight days of junior is circumcised in Genesis and Leviticus, injure and injury are related to junior 幼 in etymology.

In the third etymology, ancestor has aster and coant of count for biblical nation's ancestor Abraham to count stars (Section 3.7.6. Aunt as father's sister). In addition, ancestor has stone, when Jesus instructed in Matthew 3:9 (Matthew 1st century) and Luke 3:8 (Luke, 1st century) to "Produce fruit in keeping with repentance. And do not begin to say to yourselves, 'We have Abraham as our father'. For I tell you that out of these stones" GOD can raise children for Abraham. In John 8:37-39 (John, 1st century), "Abraham is our father". Apparently, all etymologies of ancestor point to Abraham.

Bible declares GOD in the highest purity - no wife, no gender, and no genealogy, among the numerous rationales for truth. In contrast, ancient myths heavily described imagined divinities of genders, parental birth and sexual relationship. Even Zeus had plenty of affairs. Hera was angry with her husband Zeus, since he had impregnated Leto, giving birth to Apollo and Artemis. Apollo harassed Callisto and she conceived Arcas. However, biblical description is beyond human imagination.

It must be pointed out that in addition to Adam and Eve, GOD created additional human ancestors (Du, 2020f). In Genesis 1:27-28 (Moses, 2nd millennium B.C.a), "male and female HE created them. GOD blessed them" rather than cursing Adam, and they could "fill the earth" and eat from any tree, rather than residing within only Eden garden without permission to eat from a forbidden tree. This is why after killing the only sibling Abel, the first son of Adam Cain worried that whoever met him would kill him.

\subsubsection{The First Six Ancestors of China}

The six initial ancestral leaders of ancient China，炎黄虫尧舜禹, all match biblical burnt offering and worship in etymology. 炎 has fire after fire 少, 黄 黃 has bull head with horns on fire of altar, 虫 has horns $\bigcup$ of bull $\Psi$ (牛/牛), 堯 装 has to burn 燒, 舜 has split hoof $\ngtr$ ₹ of clean offering (Du, 2019a;2019b;2019c), and 
禹它 is worshiper with scepter. coexistence is from mutual transformation of scepter and serpent, as in Exodus 4:2-5 (Moses, 2nd millennium B.C.b) "What is that in your hand?" "A staff," Moses replied. "Threw it on the ground." Moses threw it on the ground and it became a snake, and he ran from it. Then THE LORD said to him, "Reach out your hand and take it by the tail." So Moses reached out and took hold of the snake and it turned back into a staff in his hand. $\&$ can also be interpreted as horns and tail, giving rise to 它's alternative interpretation as worshiper with offering. 禹 was father of the first king of the first dynasty of China around B.C. 2070, the legendary hero who controlled leftover floods from humidity after Noah's flood more than four millenniums ago in perfect time match (Sima, 1st century B.C.).

\subsection{Race}

族 race is archer with arrow 矢, as Esau, Ishmael and Nimrod were all archers. Genesis 36 (Moses, 2nd millennium B.C.a) talked for an entire page about "the chiefs descended from Esau, by name, according to their clans and regions: Timna, Alvah, Jetheth, Oholibamah, Elah, Pinon, Kenaz, Teman, Mibzar, Magdiel and Iram. These were the chiefs of Edom, according to their settlements in the land they occupied". Ishmael "lived in the desert and became an archer". In Genesis 21:18-25:18 (Moses, 2nd millennium B.C.a), "listed in the order of their birth: Nebaioth the firstborn of Ishmael, Kedar, Adbeel, Mibsam, Mishma, Dumah, Massa, Hadad, Tema, Jetur, Naphish and Kedemah. These were the sons of Ishmael, and these are the names of the twelve tribal rulers according to their settlements and camps." The earliest biblical archer was Nimrod, "who grew to be a mighty warrior on the earth. He was a mighty hunter" in Genesis 10:8-10 (Moses, 2nd millennium B.C.a). Warrior (arrowir) has arrow, indicating a definitive conclusion that words match not only sound but also biblical meaning.

To race, to run, is grace, as in Genesis 19 (Moses, 2nd millennium B.C.a) angels urged Lot, "Hurry and get out of this place". "Flee to the mountains"! He and his two daughters fled to a cave. They got their father to drink wine and slept with him, but he was not aware of it. "So both daughters became pregnant by their father. The older daughter had a son, and she named him Moab; he is the father of the Moabites of today. The younger daughter also had a son, and she named him Ben-Ammi; he is the father of the Ammonites”. 配酸配 mate or spouse has the affix of wine 酒. Drinking wine by Philistines in Samson's wedding is additional interpretation. Wedding has wine. In the city of Sodom, the angels "reached out and pulled Lot back into the house and shut the door", and Lot told them that he "has found favor in your eyes, and you have shown great kindness", so that 恩 grace has 大 man in house 口, and 因 cause has cave man. "Lot went out and spoke to his sons-in-law, who were pledged to marry his daughters", so that in-law 姻 has man related to his room of mercy. 配 also means to assign or prepare anointing oil, perfume or wine. In Numbers 4:47-48 (Moses, 2nd millennium B.C.d), "each was assigned his work and told what to carry." To assign is to assist in igniting fire, as "The sons of Aaron the priest are to put fire on the altar and arrange wood on the fire."

\subsection{Clan}

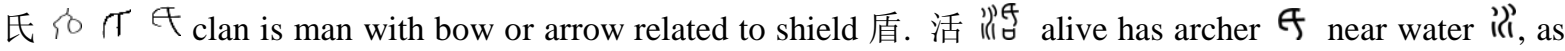
Hagar thought, "I cannot watch the boy die", and GOD "opened her eyes and she saw a well of water. GOD was with the boy as he grew up. He lived in the desert and became an archer." Additional etymologies of clan is the native nasal in Genesis 2:7 and language in 11:9.

氏 壬 represents bottom 底 and low 低, as where arrow arrives is earth. 抵 is to arrive or reach, for instance, to

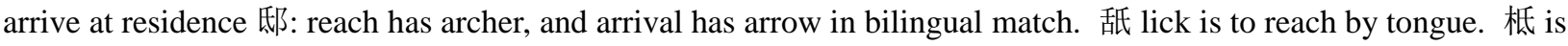


tree’s bottom. 骮 is the bottom of spine. When sun arrives at the lowest level, sunset 昏 is in marriage 婚, as in Genesis 29:23 (Moses, 2nd millennium B.C.a) "when evening came, he took his daughter Leah and gave her to Jacob, and Jacob lay with her".

\subsection{Lineage and Tribe}

裔 lineage is related to linen of tabernacle and 衣 garment of priests from Levi lineage. 系 lineage/tribe has the affix of textile糸系条, tricolor (red, blue and purple) threads or twisted linen. In etymology, line is linen, and tribe is tricolor thread. In addition, tribe is to contribute dissected offering in pair. To align is to align linen yarns, and ligation is to connect yarns. 系 also means to tie cord, as in Numbers 15:38-41 (Moses, 2nd millennium B.C.d) "Throughout the generations to come you are to make tassels on the corners of your garments, with a blue cord on each tassel.” Thus, 緊 tight/stringent is the tied tassels, and also related to Tamar's lineage in Genesis 38:27-30 (Moses, 2nd millennium B.C.a). "As she was giving birth, one of them put out his hand; so the midwife took a scarlet thread and tied it on his wrist".

\subsection{Offspring}

The etymology of offspring is off spring of Beer Lahai Roi. "The angel of THE LORD found Hagar near a spring in the desert; it was the spring that is beside the road to Shur." "I will so increase your descendants that they will be too numerous to count". "She gave this name to THE LORD WHO spoke to her". "That is why the well was called Beer Lahai Roi; it is still there, between Kadesh and Bered. So Hagar bore Abram a son, and Abram gave the name Ishmael".

\subsection{Descendant}

Containing end/den as a newly identified affix of footstep in etymology ( $\mathrm{Du}, 2019 \mathrm{~b}$ ), descendant is related to successor when the angel descended to Hagar. To send, attend, ascend and descend all have footstep. For instance, stop 止 at Ararat mountain 山 is dental 齿, and two humans in mating is tooth, because in Genesis 8:4-9:9 (Moses, 2nd millennium B.C.a) "the ark came to rest on the mountains of Ararat". "As for you, be fruitful and increase in number; multiply on the earth and increase upon it." "Everything that lives and moves will be food for you".

Census is related to descendant, because in Numbers 1:2 (Moses, 2nd millennium B.C.d) "Take a census of the whole Israelite community by their clans and families, listing every man by name". "And so he counted them in the Desert of Sinai: From the descendants of Reuben the firstborn son of Israel...From the descendants of Judah......From the descendants of Naphtali...according to the records of their clans and families...The total number was 603,550 ".

\subsection{Family and Relatives}

Because early relatives were worshipers around altar, family is flame of burnt altar, and relative is related to altar in correlation ( $\mathrm{Du}, 2020 \mathrm{~d})$. Priests alternate in offerings at altar. 亲 relative has $>$ division of offering (exactly how Abraham performed in Genesis 15:10 (Moses, 2nd millennium B.C.a) and $*$ bull under divine cloud $\bar{\zeta}$. Relatives and friends cut offerings and fired them at altar, so that kinship is akin to kindle. 宰 to slaughter is to sacrifice taurus as a related word, solving thousands of years of word riddles on relatives, presenting linguistic evidence that the etymologies of relatives are definitively biblical, and facilitating meaningful vocabulary acquisition in both languages.

\subsubsection{Father}

As relatives are related to altar, father heats fat on thermal altar in semantic origin (Du, 2020d). Aaron, high 
priest and father of his priestly sons, burnt all fat on altar (Moses, 2nd millennium B.C.c). 父 parental parent cuts offering in pair $\$ to be burnt on firewood, as the earthly father of faith Abraham "brought all these to him, cut them in two and arranged the halves opposite each other" in Genesis 15:10 (Moses, 2nd millennium B.C.a). Addition of a pair of offered meats 罗 gives rise to dad 爹. Patri and parent are to cut in pair and to parts, giving rise to paternal, patrimony, patriarch, patronymic, patronize and patron. Therefore, multiple languages exhibit identical biblical etymology for such a most frequently cited word. Patriot has pair to cut in pair at altar like Abraham did. In etymology, patriotism is parental worship in faith to HEAVENLY FATHER.

\subsubsection{Mother}

Maternal mother is also related to thermal altar. 母 mother was known by linguists as the morphology of a woman $K$ with two mammary parts, although the second interpretation of this basic word involves cut to two $:$. Mother is related to cut (tom) offering to thermally burn at altar. In the third etymology, mother is her motion, as Eve moved out of Eden garden.

毒羙 venom has tree 丰 and the symbolic mom母 with the highest resemblance to no 冊, as the forbidden fruit should not be taken. Toxin is to sin, and links to noxious and toxic. Poison has son's poi, foot, as "he will strike your head, and you will strike his heel" in Genesis 3:15 (Moses, 2nd millennium B.C.a). Such biblical words could not have been created by human, as it does not fit common sense to describe mom in this way, indicating divine creation of initial languages.

\subsubsection{Father in Law and Mother in Law}

In Exodus 18 (Moses, 2nd millennium B.C.b), “Jethro, Moses’ father-in-law, together with Moses' sons and wife, came to him in the desert". "Jethro, Moses' father-in-law, brought a burnt offering and other sacrifices to GOD”. Father in law, 岳父, has 岳 mountain, and indeed provided Moses legal advice in law, "But select capable men from all the people — men who fear GOD, trustworthy men who hate dishonest gain — and appoint them as officials over thousands, hundreds, fifties and tens. Have them serve as judges for the people at all times, but have them bring every difficult case to you; the simple cases they can decide themselves." "Moses listened to his father-in-law and did everything he said. He chose capable men from all Israel and made them leaders of the people, officials over thousands, hundreds, fifties and tens. They served as judges for the people at all times.”公婆, father and mother in law, have division of offering $\mathcal{} \backslash$, smoke from fire $己$, and water wave 波, because of Noah's burnt offering and his wife's three daughters in law.

\subsubsection{Uncle as Father's Brother}

In addition to the relationship between 叔 uncle (father's brother) and 菽 lentil (Du, 2019c), 粥 stew has an affix of crop $\div$ and plenty of bows 弓, as the archer Esau ate lentil stew. "Jacob was a quiet man, staying among the

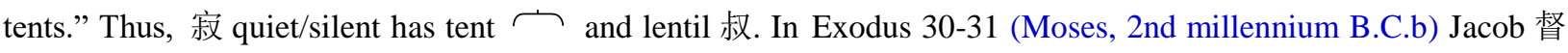
watched over his uncle Laban's flocks. 戚 kin has lentil 尗, as Jacob and Esau belonged to the kinship of Abraham who kindled burnt offering. 戚 has the affixes of legume 菽 and weapon 戈, but also means sorrow 慽, as the arrow shooter lost the elder brotherhood and wept in Genesis 27:30-38 (Moses, 2nd millennium B.C.a). Human does not create the word of relatives to be sorrowful, as these words were created divinely.

\subsubsection{Uncle as Mother's Brother}

Uncle is related to vessel. 舅 uncle (mother's brother) is man 男 near ark as a large container 臼, since in 
Genesis 11:11 (Moses, 2nd millennium B.C.a) "Shem lived 500 years and had other sons and daughters", and these sons were uncles of the children of these daughters. Shem was also uncle of the children of his two brothers Ham

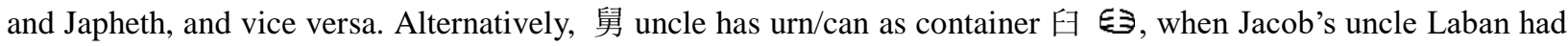
Jacob's mother as a sister carrying water jar. In Genesis 24:12-25:26 (Moses, 2nd millennium B.C.a), "Rebekah came out with her jar on her shoulder" and "Rebekah had a brother named Laban".

\subsubsection{Aunt as Father's Sister}

姑 aunt's etymology is related to how ancestors could count 數 stars, 如 if indeed they could count them. In Genesis 15:1-22:17 (Moses, 2nd millennium B.C.a), GOD took Abraham outside and said, "Look up at the heavens and count the stars - if indeed you can count them." “So shall your offspring be.”數 number has aunt 姑 (岑，叀) including radiating starlight 十, if 如, and hand with tool to cut offering (Du, 2019c). Whether is related to heat at thermal altar, and if is of fission to cut offering, answering why whether means if in grammar. Sarah is aunt of Ishmael and sister of Abraham. Star or aster (the affix of star in Latin and Greek) is in ancestor, for ancestor to count aster, and ancestor has coant to count. "I will surely bless you and make your descendants as numerous as the stars in the sky and as the sand on the seashore." Accordingly Abraham offered heifer. Later he offered calf too. Thus, 星 star has taurus/heifer 牛, and two translations of descendant, 后向 and 嗣, have hand on altar. As Abraham cut offering to two, 沙 sand sounds part of descendant and has cut to two 八.

姑 aunt has if 如, also because whether Sarah was wife, and if there were ten 十 righteous people. In Genesis 12:11-13 (Moses, 2nd millennium B.C.a), Abraham did not consider it worthy to shed blood because of sharing wife, "I know what a beautiful woman you are. When the Egyptians see you, they will say, 'This is his wife.' Then they will kill me but will let you live. Say you are my sister, so that I will be treated well for your sake and my life will be spared because of you.” In Genesis 20:2-16 (Moses, 2nd millennium B.C.a), Abimelek asked Abraham, "What was your reason for doing this?" Abraham replied, "I said to myself, 'There is surely no fear of GOD in this place, and they will kill me because of my wife.' Besides, she really is my sister, the daughter of my father though not of my mother; and she became my wife. And when GOD had me wander from my father's household, I said to her, 'This is how you can show your love to me: Everywhere we go, say of me, "He is my brother." , "In Genesis 18:1-33 (Moses, 2nd millennium B.C.a), Abraham pleaded for the city of Sodom. "May THE LORD not be angry, but let me speak just once more. What if only ten can be found there?" HE answered, "For the sake of ten, I will not destroy it."

姑 aunt is also un at, not at, as Ishmael and Hagar were driven away by this aunt who only wanted Isaac to inherit, which distressed Abraham. 菇 mushroom resembles the great tree of Mamre or Abraham and Sarah’s tent. 估 to estimate has semi (cut to two) at altar. Old is flood, 古古 ancient has 十 network of burnt altar $\forall$ (can is to burn), and archaic is to char offering near ark, linked to words including stabilization 固 (of the ark), 祜 blessing (to Noah), water 沽, lake 湖 (temporarily formed after the flood), wither 枯, 故 death, 鼓 guilt, and 怙 persistence in crimes (because "the earth was corrupt in GOD'S SIGHT and was full of violence" as the reason of flood in Genesis 6:11-9:10 (Moses, 2nd millennium B.C.a). "HE sent a wind over the earth, and the water receded" until 涸 drying. 詁 is linguistic transcription of 古 archaic words. 考古 archaeology is to investigate where the ark was. As 古 archaic transnotes ark, 姑 aunt is also any daughter of Genesis 11:11 (Moses, 2nd millennium B.C.a) as aunt of the children of her siblings, when Shem "had other sons and daughters". 


\subsubsection{Aunt as Mother's Sister}

姨, aunt as mother's sister, has 弓 bow man大 and could be Mahalath, a daughter 女 of the archer 弓大 Ishmael when the hunter and archer Esau "went to Ishmael and married Mahalath, the sister of Nebaioth and daughter of Ishmael” in Genesis 28:9 (Moses, 2nd millennium B.C.a). Leah and Rachel, sisters 姐妹 and wives of Esau’s brother Jacob, are also aunt's etymology, as they were aunts to each other's children, because 大弓 also means a great man to bow in worship, Jacob bowed seven times as he greeted his brother in Genesis 33:3 (Moses, 2nd millennium B.C.a), and Esau and Jacob switched birthright in Genesis 25:33 (Moses, 2nd millennium B.C.a), so that Jacob became Esau (Section 3.7.12.2). With S/N rotation, one etymology of switch is twin (twis), for GOD to twist Jacob's tendon during wresting.

\subsubsection{Wife of Father's Brother}

审 judge is related to GOD 神 because of final judgement. Moses’ wife Zipporah was 婶, wife of father's brother, to the four sons of Moses' elder brother Aaron. She was the woman 女 of Moses, a biblical judge 审 whose father in law was her father Jethro.

\subsubsection{Male, Female, Man and Woman}

男 man/male has two biblical interpretations: 鸟 arm at burnt altar that has flame and grating 田, and farm (田) laborer (力 S), as in Genesis 3:14-19 (Moses, 2nd millennium B.C.a) "through painful toil you will eat of it all the days of your life. It will produce thorns and thistles for you, and you will eat the plants of the field".

女 女 woman is written in direct morphology. Woman or female is derived from man or male, as Eve was from Adam's rib 肋 $⿵$ 剓 in Genesis 2:21-23 (Moses, 2nd millennium B.C.a). 妥 ready has lady 女 to be taken $\pi$ from Adam. The etymology of woman has own, because Eve was from Adam's own bone. "GOD made a woman from the rib HE had taken out of the man. The man said, "This is now bone of my bones and flesh of my flesh; she shall be called 'woman', for she was taken out of man."' Because Eve was from Adam's flesh, female is related to self.

公 male has to cut meat in duality. Some meat on altar's flame is worshiper's later meal. Leading public worship interprets why 公also means public and duke. With an affix of footstep $\ngtr$, 俊 掭 pretty is $刀$ Sarah to $\ngtr$ trip with a male 公 (her husband 老公) who cut offering to two ノ. In Genesis 11:31-15:18 (Moses, 2nd millennium B.C.a), Sarai (Sarah's initial name) was “a beautiful woman” and Abram (Abraham's initial name) "took his wife Sarai, his nephew Lot, all the possessions they had accumulated and the people they had acquired in Haran, and they set out for the land of Canaan, and they arrived there." "Abram brought all these to him, cut them in two and arranged the halves opposite each other" before $\checkmark$ "smoking firepot with a blazing torch appeared and passed

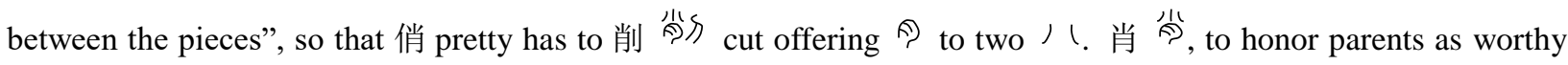
children, is to worship by cutting offering is to two ) ( ( Du, 2020d), an astonishing etymology to the world that absolutely matches bible.

\subsubsection{Husband and Wife}

\subsubsection{Etymology of Husband and Wife}

夫 husband is to banish (一) human 大 $\pi$, to ban two people二人 from sacred land, when "GOD banished him from the Garden of Eden”. 妻卷 wife is related to woman and female, and has 芝 woman's hand $\curvearrowright$ to touch the forbidden tree $\Psi$. 苯 means dense and thick plants, as Eden was full of plants. 凄 and 悽 are cold in weather and sad in mood, as in Genesis 3:7-10 (Moses, 2nd millennium B.C.a) "HE was walking in the garden in the cool of the 
day, and they hid from THE LORD GOD among the trees of the garden". "GOD made garments of skin for Adam and his wife and clothed them" before driving them out, so that cold is related to cloth and relocation.

\subsubsection{Etymology of Bride and Bridegroom}

To ride is bride to hide face, and bridegroom is for bride to go to room, as in Genesis 9 24:7-67 (Moses, 2nd millennium B.C.a) "they sent their sister Rebekah on her way". "Rebekah and her attendants got ready and mounted the camels and went back". "She took her veil and covered herself" before"Isaac brought her into the tent of his mother Sarah, and he married Rebekah. So she became his wife”. 婦 wife/woman and 歸 return, originally meaning to sent a woman away for marriage, has veil 巾, tent $\longrightarrow$, and the affixes of relocation 追 (B) and migration 止 $\forall$. Bridegroom has migro ride, when Abraham's servant returned to the bridegroom Isaac with bride in this ride. 帚 groom and woman 婦 have room, groom cleans a room, and broom is made from long and hard grass 菅, as Rebekah answered the matchmaker, "we have plenty of straw and fodder, as well as room for you to spend the night". Then her brother Laban "prepared the house and a place".

\subsubsection{Affix of Location 追}

The affix of locations 追官, in land 陸官塋 and cities such as 阜新 and 蚌埠, has two locations 口. Thus, 追 chase has 追, and 陵官桟 tomb has motion 追 (Du, 2020d). 绾, to drop rope, has the affixes of textile 糸宗 and motion 追, because In Joshua 2:1-21 (Joshua 2nd millennium B.C.) Rahab let two chased spies "down from the window by a cord, for the house where she was living was on the town wall." 陰 官令 means dark, spiritual world,

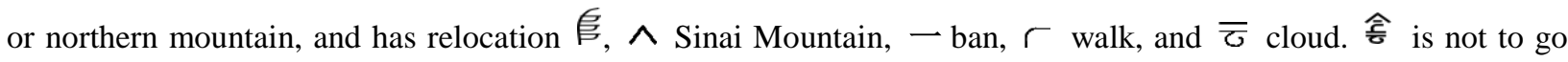
near the mountain in Exodus 19:9-19. "I am going to come to you in a dense cloud". "Be careful that you do not go up the mountain or touch the foot of it." "The people remained at a distance, while Moses approached the thick darkness where GOD was.” Among multiple interpretations, alarm is ram's horn under this mountain with loud sound under cloud, or arm to prevent access to Tent of Meeting filled with cloud. 險唡 jeopardy is for these

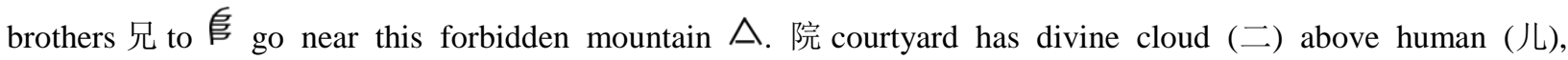
secluded 隐 with barrier 障 for segregation 隔. 卢 can also mean brick to brick, stone to stone, and stairway to stairway 阶阼陔. 隙 is fissure between two bricks of wall. 陛 emperor initially meant escalating stairway. With worship 祭 to include divine radiating cloud $\bar{\pi}$, 際/际 is space between two walls of bricks or stones, to defend 防 temple behind city wall 隍.

\subsubsection{Etymology of Marriage and Divorce}

Marriage has Mary to marry, because in Matthew 1:20 (Matthew 1st century) an angel appeared to Joseph in a dream, “Joseph son of David, do not be afraid to take Mary home as your wife”, so that 娶 marriage has to take (取) woman (女). In alternative etymology, 娶 to wed is to 取 take woman 女 to weep, as in Deuteronomy 21:10-13 “if you notice among the captives a beautiful woman and are attracted to her, you may take her as your wife" after she "mourned her father and mother for a full month".

Certified record to void is divorce, as in Deuteronomy 24:1-3 "he writes her a certificate of divorce". In Matthew 19:7-8 (Matthew 1st century), “"Why then,” they asked, "did Moses command that a man give his wife a certificate of divorce and send her away?" Jesus replied, "Moses permitted you to divorce your wives because your hearts were hard". 


\subsubsection{Etymology of Widow and Bachelor}

Widow is wife void of husband. Alternatively, widow is double wives, as it is frequent in biblical tradition for a widow to become wife of her deceased husband's brother. In Genesis 38:6-30 (Moses, 2nd millennium B.C.a), "Judah got a wife for Er, his firstborn, and her name was Tamar." Er passed away. Judah gave her to his second son Onan as wife, but Onan passed away too. Judah gave her to his third son Shelah, although Shelah grew up but did not take her. In Deuteronomy 25:5, "If brothers are living together and one of them dies without a son, his widow must not marry outside the family. Her husband's brother shall take her and marry her and fulfill the duty of a brother-in-law to her."

孀 widow has 相雨 (to tell future rain) and 目霖 (to foresee/eye heavy rain), as in 1 Kings 17 (Unknown author, 1st millennium B.C.a) Elijah prophesied no rain for three years, and "there had been no rain in the land. Then THE WORD OF THE LORD came to him: "Go at once to Zarephath in the region of Sidon and stay there. I have directed a widow there to supply you with food." So he went to Zarephath. When he came to the town gate, a widow was there gathering sticks”。枝/柴 stick has wood 木 of widow. In James 5:17 (James 1st century), “He prayed earnestly that it would not rain, and it did not rain on the land". "Again he prayed, and the heavens gave rain, and the earth produced its crops."

孀 widow and wifeless bachelor 鲤 have tear 忆 (泪) from eye (目) to weep. As wifeless man who has lost wife, bachelor has rachel (Rachel) because of Genesis 29:16-48:7 (Moses, 2nd millennium B.C.a) "to my sorrow Rachel died in the land of Canaan while we were still on the way". "Over her tomb Jacob set up a pillar, and to this day that pillar marks Rachel's tomb”.

Matthew and Luke recorded two different parental lineages of Joseph that puzzled theologians for two millenniums. How could Joseph had two fathers? We interpreted it as the adoption of Joseph or remarriage of his mother. In other words, one was Joseph's biological father, the other was Joseph's stepfather. If Ruth, a widow and ancestor of Joseph, could remarry Boaz and gave birth to Obed in Ruth 4:13-22, why Joseph's mother could not remarry, if his biological father passed away? The two lineages written in Matthew 1:1-17 (Matthew 1st century) and Luke 3:23-38 (Luke 1st century) converge to David of Judah, just like Mahlon, Kilion and Boaz were distant relatives. Adoption was very common for Hebrews. Esther was the adopted daughter of Mordecai in Esther 2:15. Our conclusion was further strengthened by the only four women in the lineage of Book of Matthew, "Judah the father of Perez and Zerah, whose mother was Tamar"..."Salmon the father of Boaz, whose mother was Rahab, Boaz the father of Obed, whose mother was Ruth, Obed the father of Jesse, and Jesse the father of King David. David was the father of Solomon, whose mother had been Uriah's wife". Tamar, Rahab, Ruth and David's wife were either widows to remarry or potentially forced prostitute, who risked her life to rescue Israelite spies from the divine army without any request for money and sex but with full fear and respect of GOD, an essential action in faith that overwrote many transgressions. In Matthew 22:24-28 (Matthew 1st century), Mark 12:19-44 (Mark 1st century), Luke 7:12-21:4 (Luke 1st century) and John 4:16-18 (John 1st century), Jesus talked about widows, Moses' law on divorce, and wife with multiple husbands. Jesus' adopting father Joseph could have biological and step fathers to solve a well known puzzle why Joseph has two parental lineages, when Matthew 1:16 (Matthew 1st century) listed "...Matthan the father of Jacob, and Jacob the father of Joseph", but in Luke 3:23 (Luke 1st century) "Jesus Himself was about thirty years old when He began His ministry. He was The Son, so it was thought, of Joseph, the son of Heli”. 
The hypothesis that Matthew 1:1-17 (Matthew 1st century) was Mary's lineage and Mary was from David of Judah has no biblical basis in "......Eleazar the father of Matthan, Matthan the father of Jacob, and Jacob the father of Joseph, the husband of Mary, of whom was born Jesus", because it only mentioned husband rather than parent of Mary! Neither Jacob nor Joseph was Mary's father. We propose that Mary was from the clan of Aaron of Levi, as Luke 1:1-56 (Luke 1st century) clearly defines Mary as the relative of Elizabeth and "Elizabeth was also a descendant of Aaron". In Luke 1:28-40 (Luke 1st century), Gabriel told Mary that "Elizabeth your relative is going to have a child". "Mary got ready and hurried to a town in the hill country of Judea, where she entered Zechariah's home and greeted Elizabeth.” Mary did not concern abortion of such important Son for such hilly travel, indicating her extremely intimate relationship with Elizabeth. As the clan of priests Levites scattered throughout the entire Israel among the other eleven tribes in 48 towns according to Joshua 21 (Joshua 2nd millennium B.C.) and 1 Chronicles 6:54-60. Mary's ancestors could relocate to Nazareth, when in Deuteronomy 18:6-8 “a Levite moves from one of your towns anywhere in Israel where he is living, and comes in all earnestness to the place THE LORD will choose". The conclusion that Mary was from Aaron makes full symbolic sense, because Aaron is high priests' lineage and Jesus is High Priest of GOD.

\subsubsection{Etymology of Evil to Lie}

One etymology of devil and evil is to lie to Eve on whether Eve could live forever, and cheat is to eat, as in Genesis 3:4-5 (Moses, 2nd millennium B.C.a) the ancient serpent tempted Eve, "You will not surely die." "For GOD knows that when you eat of it your eyes will be opened, and you will be like GOD". To be like GOD includes infringing AUTHORITY to take human life, set lifespan, and discipline people. This is why absolutely we are not allowed to kill without righteousness and self defense. In Genesis 3:22 (Moses, 2nd millennium B.C.a), GOD concerned that the "man has now become like" GOD that he "must not be allowed to reach out his hand and take also from the tree of life and eat, and live forever." In new testament GOD already sent Son of GOD to establish the updated law of love, so that premature death and incurable diseases are not from GOD now, but from nature or human murder, unless it is nearer to the end of time.

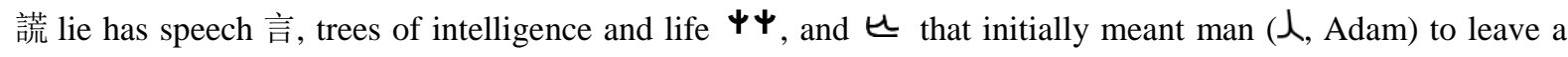
place ( $($ ) of well watered 《U Eden garden. Eve should be nervous 慌 about disobedience and death 亡. People should also be nervous about the flood resulted from violence. 荒 范 desolate wasteland has $人$ man to flee $\boldsymbol{U}$ to land of vegetation $\psi \Psi$ from watery land and flood 《《.

\subsubsection{Concubine}

嬪煩 concubine is to ban (一) 共 woman and her son's entry $(4)$ into tent $\pitchfork$ because of inheritable wealth 貝, as 貝 is the affix of wealth. In Genesis 21:9-20 (Moses, 2nd millennium B.C.a), Sarah told Abraham to expel the maidservant wife Hagar and her son, ““'for that woman's son will never share in the inheritance with my son Isaac”. The matter distressed Abraham greatly”. 妒忌 jealousy has 户 house concubine 妃, who gave birth to a son from Abraham’s own 已. 䃚 jealousy has arrow 矢 for archer, as Hagar's son Ishmael was an archer. “He lived in the desert and became an archer.” Besides to be ordered distantly outside of camp for leprosy, 疾 disorder is Sarah's initial inability to bear child and emotional disorder of uncontrollable envy. In Genesis 16:1-2 (Moses, 2nd millennium B.C.a), "Sarai, Abram's wife, had borne him no children”. "Sarai mistreated Hagar”. Concubine is also related to Reuben as in Genesis 35:22 (Moses, 2nd millennium B.C.a) "Reuben went in and slept with his father's concubine Bilhah”. 


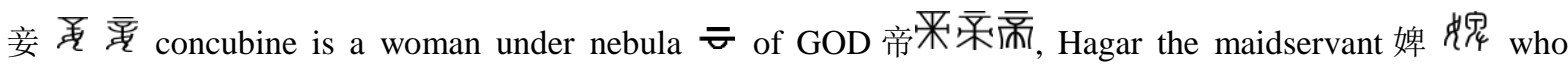
encountered a spring 泉㲾 when meeting an angel near the spring and took water from a well in Genesis 16-21 (Moses, 2nd millennium B.C.a). 裨 尒帛 help has hand ${ }^{\boldsymbol{4}}$, 尒 flock and 宁 well of water, since in Genesis 29:10 (Moses, 2nd millennium B.C.a) "he went over and rolled the stone away from the mouth of the well and watered his uncle's sheep" and in Exodus 2:16-20 “Moses got up and came to their rescue and watered their flock." 碑 牌 is stone 石 of memory and has source of water, as in Deuteronomy 27:2-5 "when you have crossed the Jordan, set up these stones on Mount Ebal". In Joshua 4:5-9 (Joshua 2nd millennium B.C.), "When it crossed the Jordan, the waters of the Jordan were cut off. These stones are to be a memorial to the people of Israel forever".

泉 spring shares etymology with origin 源, region of biblical plain. Plain 原原 has spring 泉 from water source 源. Origin and region are where rivers go in. In Genesis 2:10 and 13:10 (Moses, 2nd millennium B.C.a), “A river watering the garden flowed from Eden; from there it was separated into four headwaters" and "the whole plain of the Jordan was well watered, like the garden of THE LORD”. Spring is origin of water, and nipple is origin of milk related to nip 呷 咛. To explain is out of plain, as in Genesis 2:10-4:24 (Moses, 2nd millennium B.C.a) GOD explained that the "man has now become like one of Us, knowing good and evil" (but broke the law to eat forbidden fruit) for Adam's exile out of the well watered garden. There are multiple rationales for loss of life by the likeness but failure in obedience. For instance, wanting to become the divinity to wield authorities reserved only to cautious CREATOR.

愿 to wish, want, will or plan has plain 原 as well watered Canaan plain, where GOD wanted Abraham to move. In Genesis 12:1-4 (Moses, 2nd millennium B.C.a) GOD vowed to him the best wishes, "I will make you into a great nation and I will bless you". "I will bless those who bless you" and "all peoples on earth will be blessed through you".

\subsubsection{Brother}

\subsubsection{Etymology of Brother}

兄 elder brother is $/ \mathcal{h}$ worshiper (represented by two legs) at altar $\boxminus$. High priest Aaron was such an elder brother of Moses. In alternative interpretation, 兄 elder brother has altar $\square$ of stone 石, as a stone was pillow of spiritually elder brother Jacob in Genesis 28:11-22 (Moses, 2nd millennium B.C.a). "Early the next morning Jacob took the stone he had placed under his head and set it up as a pillar and poured oil on top of it."

In addition, brother has broth, when twins exchanged birthright for broth. In Genesis 25:27-27:4 (Moses, 2nd millennium B.C.a), "Once when Jacob was cooking some stew, Esau came in from the open country, famished. He said to Jacob, "Quick! Let me have some of that red stew! I'm famished!"” "So he swore an oath to him, selling his birthright to Jacob. Then Jacob gave Esau some bread and some lentil stew." Thus in etymology, stew is related to twin, and 饿 famine has mine 我. 餓 hunger is from hunter to have 我 me to eat 食. This is the definitive biblical etymology of hunger. In addition, 饉 to starve is to stand near river, and has taurus 革 to eat 食, because in Genesis 41:1-32 (Moses, 2nd millennium B.C.a) "the cows that were ugly and gaunt ate up the seven sleek, fat

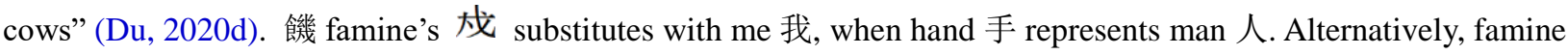
has 幺幺, twins Esau and Jacob, 食 food, 戈 weapon, and 人 man.

獵南毗 hunt is to hunt creatures with split hoof EE burnable on fire ( $($ from altar's bronze grating $\otimes$. Similar structure of altar with grating is also in thunder 雷 and hundred 百. Ancient people would not be frightened 
by a few thunderstorms to be in superstition. They were in piety because of GOD or angels Genesis (Moses, 2nd millennium B.C.a). As no one can see THE FACE OF GOD and still be alive, most ancient people imagined idols in fairy tales. Only Hebrews recorded accurately, because they were divinely revealed. In the past millenniums, people thought that hunt 獵 resembled a prey with hair, trunk, legs and tail, and hypothesized that x might mark target, although it marks the grating of altar. Such words prove the key claim in Genesis 11:7-9 (Moses, 2nd millennium B.C.a) that "THE LORD confused the language of the whole world".

\subsubsection{Twin Brothers Esau and Jacob}

\subsection{Bow}

Esau was an archer. In Genesis 25:27-27:41 (Moses, 2nd millennium B.C.a), "Esau became a skillful hunter". "Now then, get your weapons-your quiver and bow-and go out to the open country to hunt". This spiritually

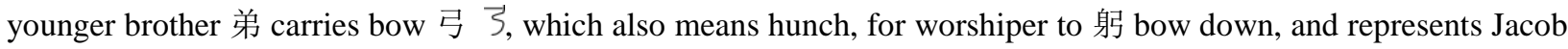
in this regards. 梯 stairway has this younger brother 弟 by birth, from Jacob's dream of stairway after switched birthright. 第 order is redor, red person, and has bow 弓 and two individuals 个个, as "the first to come out was red, and his whole body was like a hairy garment; so they named him Esau." "After this, his brother came out, with his hand grasping Esau's heel; so he was named Jacob." "Your brother Esau is consoling himself with the thought of killing you." "Esau held a grudge against Jacob because of the blessing his father had given him". "The days of mourning for my father are near; then I will kill my brother Jacob", so that murder is of red dermal skin. Esau should have wished his brother Jacob the best, and was abundantly blessed through Jacob.

Although brothers almost killed them, in Genesis 33:3-43:33 (Moses, 2nd millennium B.C.a) Jacob "bowed down to the ground seven times as he approached his brother", and Joseph also respected brotherhood in observance of fraternal seniority 悌, a core value in Judaism christianity and confucianism. "The men had been seated before him in the order of their ages, from the firstborn to the youngest; and they looked at each other in astonishment." "Is this your youngest brother, the one you told me about?" "Joseph hurried out and looked for a place to weep". Thus, tear 涕 has brother 弟. In addition, to cry has archer, to weep links weapon, sorrow and borrow's orrow involves arrow, and one etymology of sorrow is arrow man. Jacob said to his mother Rebekah, "my brother Esau is a hairy man, and I'm a man with smooth skin". "I would appear to be tricking him" but Rebekah insisted, "Just do what I say", cooked tender goats, "took the best clothes of Esau" "and put them on" Jacob, and "covered his hands and the smooth part of his neck with the goatskins", so that 佯/装 to pretend has 人 human goat 羊 and clothes 衣. Issac blessed Jacob and "indeed he will be blessed!" "When Esau heard his father's words, he burst out with a loud and bitter cry", although "He too prepared some tasty food and brought it to his father" in Genesis 27:33-34 (Moses, 2nd millennium B.C.a), so that 递, to bring something to someone, has brother弟. 表會 surface has $₹$ fur. 衰裔, old and weak, has fur and clothes 衣, as in Genesis 27:1-40 (Moses, 2nd millennium B.C.a) “Isaac was old and his eyes were so weak" and touched Jacob, “Are you really my son Esau?” To exam is to exam meat. To check 檢 is to check chef, whether Jacob was that day's chef Esau, and has twin brothers 兄兄 under Isaac's tent for Isaac to tremble 兢 when he knew that he blessed Jacob between these two siblings, so that tremble is related to bless, and sibling is related to blessing.

Esau was equipped with quiver. In Genesis 27:3-24 (Moses, 2nd millennium B.C.a), Isaac told Esau, "get your weapons - your quiver and bow - and go out to the open country to hunt some wild game for me. Prepare me the kind of tasty food I like and bring it to me to eat”. 疾 quick has arrow 矢, and quote 引 has bow 弓. 疑委芯 doubt has double sons 子 $\mathcal{S}$, Jacob to 擬 imitate Esau and 秃 Esau with arrow 矢, who went $\mathbb{E}$ out to hunt. Resembling letter $\mathrm{t}$, $ヒ 匕$ is human in side view. However, letter $\mathrm{T}$ represents altar, indicating that the meaning of English 
letters is case sensitive. Isaac asked Jacob, "How did you find it so quickly" and "whether you really are", when Jacob 挨 went close to him. 强 powerful has to bow 弓 $\vec{\xi}$ at altar $\square$ for Moses with staff of snake $\dot{\imath}$, as bowing at altar is spiritually strong. 强 strength is although (虽) to bow (弓). Although worshipers bow down, they are in

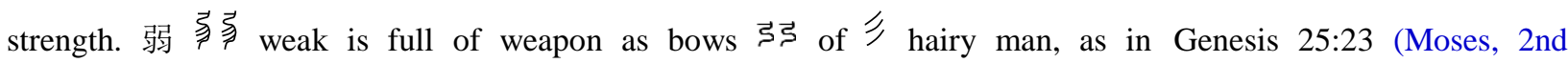
millennium B.C.a) "one people will be stronger than the other, and the older will serve the younger".

驽 bow of another biblical archer Ishmael has bow弓, hand $凤$ and 共 woman servant 奴, for bow to link woman. Linguists could be puzzled by why woman rather than man or servant rather than officer was in this weapon of bow, and hypothesized that 㛎 was created phonetically by borrowing 奴’s sound. Such hypothesis of semantic origin that dominated the linguistic field must be completely revised, as words were apparently created to match both biblical meaning and sound. For the first time in history, systematic evidence is presented for the revolutionary conclusion that words were divinely created predestinedly to multilingually mutual match in definitive etymology based on the historical scroll bible (Du, 2019a;2019b;2019c;2020a;2020b;2020c;2020d;2020e).

\subsection{Twin Brothers and the Affix 幺}

Twin is to win, as Jacob won divine wrestling. 幺幺 symbolizes twins 卛, as they touched each other 9 in birth, and the yarn of three colors 条 represents lineage. 幼 junior is to join 8 , for the twins to join each other in birth, and juvenile is a derived word. 玄, to multiply in population, has 幺幺. "Esau settled in the hill country of Seir" and hill 巒 has 幺幺. This twin archer crook 彎 bow弓. 戀, to be attached to and adore, is the most famous biblical love between Jacob and Rachel. In Genesis 29:18-30 (Moses, 2nd millennium B.C.a), "Jacob was in love with Rachel". "So Jacob served seven years to get Rachel, but they seemed like only a few days to him because of his love for her.” 變 change is to exchange twin 卛 who exchanged birthright, as Genesis 25:23 (Moses, 2nd millennium B.C.a) said 言 that between the twins the older would serve the younger 幼. 拗 to break is from Genesis 30:37 (Moses, 2nd millennium B.C.a). "Jacob, however, took fresh-cut branches from poplar, almond and plane trees and made white stripes on them by peeling the bark and exposing the white inner wood of the branches." Thus, break has bark of branch to breach. 鑾, tinkling bell in temple, is every gold bell around hem of priest's robe when entering and exiting tabernacle in Exodus 28:33-35 (Moses 2nd millennium B.C.b).

条 is the main affix of textile (Xu, 100-121 A.D.). 藥 drug has two affixes of plant, firelight from burnt altar and 幺幺 split textile, as leprosy patients tear their clothing apart. In Leviticus 13:45-46 (Moses, 2nd millennium B.C.a), "The person with such an infectious disease must wear torn clothes, let his hair be unkempt, cover the lower part of his face and cry out, 'Unclean! Unclean!' As long as he has the infection he remains unclean. He must live alone; he must live outside the camp." Thus, pharmacy has camp separation, when Pharisee means the separated. Misery has semi as halves, as Hebrews tear clothes apart in misery. 顯 to reveal is Moses' veil, and has woven threads 絲, designated place $\boxminus \odot$ and worshiper 頁, as in Exodus 28:2 "Make sacred garments for your brother Aaron, to give him dignity and honor." To appear has to pair, as when GOD appeared in vision, "Abram cut them in two. He placed the halves opposite each other" in Genesis 15:10 (Moses, 2nd millennium B.C.a). 濕 wet has textile as in Leviticus 6:27 (Moses 2nd millennium B.C.c) "if any of the blood is spattered on a garment, you must wash it in a holy place". 濕 humid is related to human lineages 幺幺 also due to covenant through Noah and his sons when climate was humid after flood. In addition, 濕 humid has two people (di hum) rather than one, as in Genesis 11:4-7 
(Moses, 2nd millennium B.C.a) they said, "let us build ourselves a city, with a tower that reaches to the heavens, so that we may make a name for ourselves and not be scattered over the face of the whole earth." But GOD scattered them and confused languages, apparently not fully trusting but checking and balancing humans. What if they all planned to rule on throne and be violent again? Numerous words reflect the great flood, as testified recently (Du, 2019a;2019b;2019c;2020d).

In Genesis 31:23-36:8 (Moses, 2nd millennium B.C.a) “He offered a sacrifice there in the hill country”. 崗岗 网 hill has 山 $৬$ mountain and 冈, altar with grating or firewood. 率 lead, wrestle 摔 and wrench 攣 also have 么, as in Genesis 32:22-32 "Jacob got up and took his two wives, his two maidservants and his eleven sons and crossed the ford of the Jabbok. After he had sent them across the stream, he sent over all his possessions. So Jacob was left alone, and a Man wrestled with him till daybreak. When The Man saw that He could not overpower him, He touched the socket of Jacob's hip so that his hip was wrenched as he wrestled".

前 forward has arrow 箭, 後 $引$ 要 behind has 幺 of junior 幼 to grasp foot $\forall$, as in Genesis 25:23-27:29 (Moses, 2nd millennium B.C.a) Esau was an archer and "his brother came out, with his hand grasping Esau's heel”, although "the older will serve the younger". Also in 1 Samuel 20:22-38 (Samuel 1st millennium B.C.), "But if I say to the boy, 'Look, the arrows are beyond you,' then you must go". In Luke 13:23-30 (Luke 1st century) and Mark 9:35-10:31 Mark (1st century), "who are first will be last, and the last first." "If anyone wants to be first, he must be the very last, and the servant of all."

統晾考 union is related to junior, because a worshiper (represented by legs) / 1 should put on new clothing 条 in unity with Son $\boldsymbol{\sigma}$ (head upside down in delivery). In John 17:20-26 (John 1st century), "I pray also for those who will believe in Me through their message, that all of them may be one, FATHER, just as YOU ARE in Me and I Am in YOU. May they also be in Us so that the world may believe that YOU have sent Me. I have given them the glory that YOU gave Me, that they may be one as We Are One: I in them and YOU in Me. May they be brought to complete unity to let the world know that YOU sent Me and have loved them even as YOU have loved Me."

\subsection{Lentil}

豆 豆 lentil initially meant utensil such as food utensils in ancient literature (Xu, 100-121 A.D.), and hunt, thunder and hundred all have altar with bronze grating as a worshiping utensil. Later lentil utensil transnoted bean, involving which twin would or would not receive the benediction through Isaac, after the bean stew provided Jacob divine birthright while Esau "despised his birthright" in Genesis 25:34 (Moses, 2nd millennium B.C.a).

欺 cheat is cheit of kitchen to heat 厨 chefs' 豆 lentil stew and tasty goats at kitchen 厨, with 其 cattle on utensil. 帳 tent has elder 長, as in Genesis 26:25 (Moses, 2nd millennium B.C.a) their father Issac "pitched his tent”. 長 also means long as Esau was hairy with long hair 毛平. 失专 loss is hairy man to lose birthright. 秩稳 order is the order of brotherhood, as for broth of lentil crop 禾, Esau lost 失 elder brotherhood.

With soth of sooth and smooth, 短 short is short hair of smooth skin, and has 豆 lentil stew and 矢 arrow of the other twin. 矮 short is to shoot arrow 矢, and has lentil represented by an affix of crop 禾, and 女 woman as their mother. Their descendants claimed in Numbers 13 (Moses 2nd millennium B.C.d) Deuteronomy 1:28-2:21 (Moses, 2nd millennium B.C.e), “All the people we saw there are of great size. We saw the Nephilim”. Emites and Rephaites were also "as tall as the Anakites". "The people are stronger and taller than we are". "We should choose a leader and 
go back". In biblical etymology, giant is anti migration (gi, g+vowel is a set of affixes to go, such as go and eg of leg and geography), and espionage links to suspicion and poise na ge, stop and not going, as their report discouraged faith for GOD to claim that "Not one of you will enter the land”. In surprising bilingual biblical etymology, 諜 espionage (genepasion) has generation 世屴出, whose etymology is to block entry (er ne ge into, person not go into) (Du, 2020c).

\subsection{Wrestling}

Wrestling is the directly recorded biblical sport, when Jacob was in portage. Sport has port Jabbok, and tournament has tour and name, as during his tour Jacob was asked, "What is your name?" "Jacob," he answered. "Your name will no longer be Jacob, but Israel". 赛 contest is linked to tendon and limp 蹇 due to divine wrestling, as after this contest "he was limping". "Therefore to this day the Israelites do not eat the tendon attached to the socket of the hip, because the socket of Jacob's hip was touched near the tendon." This is biblical interconnection between contend and tendon.

竞 compete and complete 竟 are absolute bilingual match. 竟 to compete has co pe as two legs $/$ and pet as petrified stone pillow. 竞競 contend has tendon and the cloud of GOD 帝 and brothers 兄, “because you have struggled with GOD and with men" to complete 竟 the wrestling. 鏡 mirror has 竟 to reflect image, and mirror is man and "Man" at rim of water with "Man" as "mirage", when this wrestling had the most famous Image of "Man". This is how Abraham met GOD and two angels and also why Moses was only allowed to see THE BACK OF GOD in a cleft of rock in Exodus 33. The term GOD is a typical transnotion, because no one can directly use THE NAME OF GOD. 鑒 mirror was bronze, which was initially written as 金 that later represents gold. In Exodus 38:8 "They made the bronze basin and its bronze stand from the mirrors”. 境 border is the realm of the stream at Ford Jabbok for 兄 brother Jacob to compete 竟. Sinewy is strength, as Jacob could not be overpowered, so that 竟 also means to one's surprise or what on earth.

\subsection{The Affix 欠}

Switching order 次 to 欠 owe birthright, 巻欠 could be human near water, priest with hair (as priest cannot shave hairs on two sides), hairy man Esau, or Jacob smelling the scent of stew. 祝 blessing has elder brother 兄, as the spiritually elder sibling received the blessing, while his spiritually younger brother sighed 歎. 歌 歌 song has any priest with hair, to carry altar across stopped water $T$ during migration. Song and sing are to go without (no/ni) water, as in Exodus 14-15 "Israelites walked through the sea on dry ground" and Moses and Israelites sang this song, “I will sing to THE LORD”. “I will praise HIM, my father's GOD, and I will exalt HIM”. 歡 joy and 享 enjoy have person $人$ and 子 $\mathcal{F}$, although in journey to enjoy manna is also the etymology.

\subsection{Theft}

盜㸺 steal is to steal burnt offering. Steal (altes) has altar. In addition, steal is to steal wealth, for man to eat what is forbidden. It has iil water, as burnt offering is washed by water. It has priest with hair. It also has worshiping utensil with the marker of division /( for burnt offering, which is cut to pieces. Priest Eli's two priestly sons stole and ate offerings sacrificed to GOD, as described in 1 Samuel 2:12-17 (Samuel 1st millennium B.C.). In excellent consistence with this etymology, 窃 steal has Tent of Meeting , division of offering 八 and cut 切. Its 
traditional version 窲 has offering at altar with salt 卤. In bilingual match, steal has salt. In Leviticus 2:13 (Moses 2nd millennium B.C.c), "Season all your grain offerings with salt. Do not leave the salt of the covenant of your GOD out of your grain offerings; add salt to all your offerings.” Salt was quite expensive at ancient time. 偷 steal

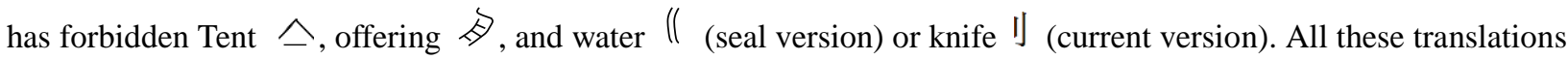
share identical biblical semantic origin, which has little statistic chance to be historical coincidence, suggesting that these words were created ahead of time to match predestined biblical events, although through whom (for instance, whether Rachel or Leah) to achieve them is decided divinely.

盜监 steal also has 行 blood in Rachel's period, 亚 Laban's divine utensil, and 帣欠 to represent one of the twins (Jacob), as in Genesis 31:19-35 (Moses, 2nd millennium B.C.a) "Rachel stole her father's household gods." "Laban went into Jacob's tent and into Leah's tent and into the tent of the two maidservants, but he found nothing. After he came out of Leah's tent, he entered Rachel's tent. Now Rachel had taken the household gods and put them inside her camel's saddle and was sitting on them." Rachel said to her father, "I cannot stand up in your presence; I'm having my period”. 窃 steal has $儿$ to cut 切 offering near tent $\Pi$, as after this search in tents for the lost item, Jacob "offered a sacrifice there in the hill country and invited his relatives to a meal". 偷 》佱 steal has $\pi$ human, mountain $\wedge$ and - to indicate boundary, as Laban said "I will not go past this heap to your side to harm you and that you will not go past this heap and pillar to my side to harm me." It also has either monthly blood of Rachel or water for washing offering (I, as well as split offering $\$$.

As a newly identified affix, $\Delta$ is in additional words and has $>$ to pair with $\langle$. For instance, it represents boat that contained male and female of each species as a major detail of ark (Du, 2019b;2019c; Moses, 2nd millennium B.C.a). It is also in 勝冬穿 victory, which has man and "Man" touching each other in divine wrestling

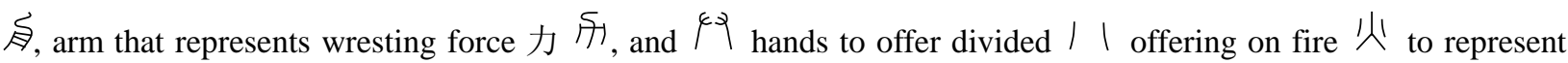
Israel. In Genesis 32:22-32 (Moses, 2nd millennium B.C.a), “After he had sent them across the stream”, GOD "wrestled with him till daybreak." "Your name will no longer be Jacob, but Israel, because you have struggled with GOD and with men and have overcome."

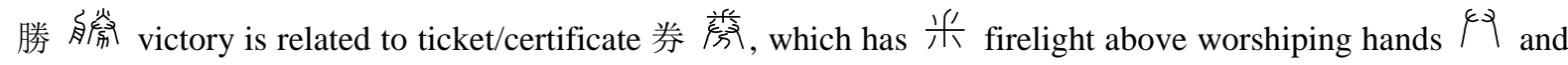
刀 knife to dissect offering, when knife (finke/finge) is represented by worshiping fingers $S$ in bilingual mutual match. After divine victory in promised land, Joshua certified all the lands and cities to twelve tribes. In Joshua 18:4-10 (Joshua 2nd millennium B.C.), "make a survey of the land and write a description of it. Then return to me,

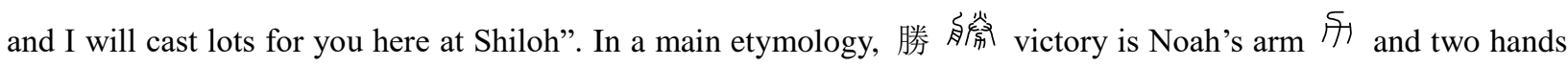
49 to offer burnt offering on fire 从火 near ark 舟 月 in Genesis 7-8 (Moses, 2nd millennium B.C.a). This is why surprisingly victor is related to vector and vehicle, and conquer is con aqua liquid to be against flood.

\subsubsection{Sister and Sister in Law}

\subsubsection{Elder Sister}

姐 elder sister is 女 woman at altar 且, consistent with worship by ancestors 祖 at altar, when the first and second sons of Adam and Eve offered offerings in Genesis 4 (Moses, 2nd millennium B.C.a). The alternative etymology of sister is to assist, as in Genesis 2:18 "It is not good for the man to be alone. I will make a helper suitable for him." GOD created a sister 姐 consisting 组 in Adam's bone to 助 assist the ancestor 祖, but later cursed 诅 怚 sad couple to 锄 remove thorns, desisting 阻 them for their failure to resist 阻 temptation, although in Genesis 1:27-31 (Moses, 2nd 
millennium B.C.a) GOD created male and female, blessed them and said to them, "Be fruitful and increase in number", and saw that "it was very good". Correspondingly, good is related to GOD, and one translation of good 好 has 女 female and 子 that means either man or son.

Another translation of sister, 姊, has woman (女) own (己) man (人), because in Genesis 2:21-23 (Moses, 2nd millennium B.C.a), GOD “took one of the man's ribs and closed up the place with flesh. Then THE LORD GOD made a woman from the rib". The man said, "This is now bone of my bones and flesh of my flesh; she shall be called 'woman,' for she was taken out of man." The etymology is also snake 5 and 人 human woman 女, or to sever 切 offered taurus $\Psi$. 剓 is a kind of cereal, as GOD told Adam and Eve toil and plants of the ground, and their first son "Cain worked the soil" in Genesis 3:17-4:2 (Moses, 2nd millennium B.C.a).

\subsubsection{Younger Sister}

妹 younger sister has woman 女 and tree or cattle未 $\mathscr{*}$, as Eve was near trees and biblical ancestors worshiped with flock and herd. 姝䗇 good lady is for woman 女 not (一) to touch a tree 木. Forbidden tree w would lead to death 誅彩 according to the speech 言 in Genesis 3:3 (Moses, 2nd millennium B.C.a). “GOD did say, 'You must not eat fruit from the tree that is in the middle of the garden, and you must not touch it, or you will die.' " This is why 未 can mean no or not yet, no for the tree of intelligence, and not yet for the tree of life. 未来 future is not to come yet. 妹 younger sister includes Leah's younger sister Rachel the shepherdess, as in Genesis 29:6-16 (Moses, 2nd millennium B.C.a) "While he was still talking with them, Rachel came with her father's sheep, for she was a shepherdess." "Now Laban had two daughters; the name of the elder was Leah, and the name of the younger was Rachel."

朱 $\Psi$ is forbidden plant $(-) \Psi$, when Moses was called by GOD in Horeb mountain, "Do not come any closer," and "though the bush was on fire it did not burn up". "Take off your sandals, for the place where you are standing is holy ground.” In Exodus 4:24-26, GOD almost 誅 䋛 executed Moses after he did not circumcise his sons. For thousands of years, linguists were puzzled by why 朱 6 can mean bright red in addition to its relationship to plant 株. The color of divine flame from burning bush of holy ground answers.

\subsubsection{Sister in Law}

嫂 sister in law is to search 搜, as Rachel (rache of search) was searched. “After he came out of Leah’s tent, he entered Rachel's tent. Now Rachel had taken the household gods and put them inside her camel's saddle and was sitting on them.” Thus, 驼 camel has 七 human and camp $\nrightarrow$. 鞍 saddle has leather 革, ↔ tent and woman 女, as several tents and women were searched by the senior 叟 Laban.

\subsubsection{Cousin}

堂 cousin of parental lineage is related to house 堂 and household. The house is Tent of Meeting $\square$ in front of altar $\forall$ with division of offering 八. 尚简 culture and custom have ) ( cut offering related to $\square$ Tent of Meeting and altar (ultur) $\circlearrowleft$. Cousins worship together around Tent of Meeting and altar with extensive biblical record.

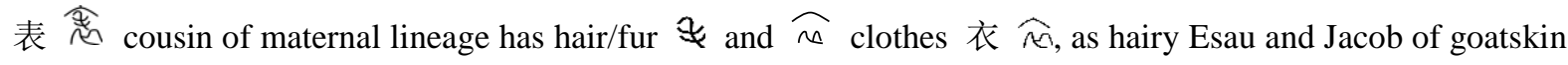
with clothes of Esau were cousins of their uncle Laban's sons and daughters Leah and Rachel. In addition, John the 
baptist was cousin of Jesus, linking cousin to acoustic, as presented next on Son and sonic sound.

\subsubsection{Son}

\subsubsection{Son, Child and Kid's Etymology}

The etymology of 童 Son as 音 Sound on ground 土 has been presented (Du, 2020d). Son is related to soni, as reflected by names too. Simeon and Simon have soni as sound. In Genesis 29:33 (Moses, 2nd millennium B.C.a), "LORD heard that I am not loved, HE gave me this one too." So Leah named him Simeon, to hear (soni) me. Simeon is to hear about the second son, cut offering in halves (semi), or divide people to halves. In Luke 2:25-38 (Luke 1st century), "Simeon blessed them and said to Mary, His mother: "This Child is destined to cause the falling and rising of many in Israel, and to be a Sign that will be spoken against, so that the thoughts of many hearts will be revealed. And a sword will pierce your own soul too."

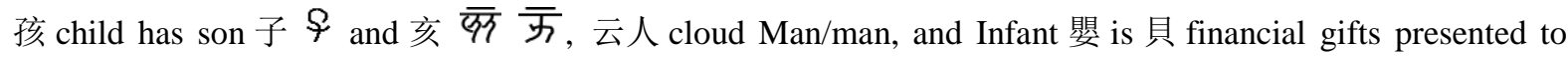
Mary, fiancée of fiancé Joseph (Du, 2019a;2020d), proving the accuracy of old and new testaments (Du, 2019a). Letter $\mathrm{j}$ directly represents junior or person in morphology $\mathcal{g}$, including head and body. Kid can be considered as clid or chid of child. In Exodus 1:16, Pharaoh said to Hebrew midwives, "When you help the Hebrew women in childbirth and observe them on the delivery stool, if it is a boy, kill him; but if it is a girl, let her live." Child is to kill worshiper ฉ. 贞/嬰 infant has split offerings and female 女 to indicate that only girls were allowed. 悖, contrary and counter to, is inverted birthright between the 勃 vigorous hunter in open country and cooker of lentil stew in

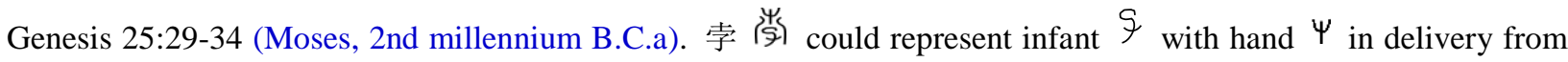
belly ? १, when Jacob held Esau's heel.

Luke 2:22-24 (Luke 1st century) records that "When the time of their purification according to the Law of Moses had been completed, Joseph and Mary took Him to Jerusalem to present Him to THE LORD (as it is written in the Law of THE LORD, "Every firstborn male is to be consecrated to THE LORD"), and to offer a sacrifice in keeping with what is said in the Law of THE LORD: "a pair of doves or two young pigeons." "This indicates that Joseph and Mary had not received treasures from Magi yet. Otherwise, such devoted couple would have offered lamb. They gave birth to Jesus at Bethlehem, went to Jerusalem for purification from Jesus' circumcision, returned to Bethlehem, met Magi and received the gifts, fled to Egypt, and then returned to Nazareth of Galilee according to Luke 2:39-42 (Luke 1st century). Jesus was misjudged to be from Nazareth rather than Bethlehem, the prophesied city of Christ when investigators checked the scripture, as Mary, Joseph, Elizabeth and Zechariah did not tell His true birthplace due to historical plan and Herod's murder. They further ruled out prophet, as in John 7:52 (John 1st century), "Look into it, and you will find that a prophet does not come out of Galilee", although Galilee emerged multiple Son's prophets such as Peter in Mark 1:16-18 (Mark 1st century) and Matthew 4:18-20 (Matthew 1st century).

瘘 goiter could have businessman carrying treasure 貝, although here the wealth is sea salt, which was expensive at ancient time. Sea salt has iodine to heal thyroid and was purchased. Human can not drink sea water but needs iodine to survive. Thus, people lived near both land and sea waters, consistent with the description of well watered plain of Genesis. 缨 ribbon is related to infant 贞, as Hebrews wear tassels with a blue cord on each tassel. "You will have these tassels to look at and so you will remember all the commands of THE LORD”. 


\subsubsection{Stone's Etymology}

Relationship between son/Son and stone are from Isaiah 28:16 and 1 Peter 2:6, "I lay a stone in Zion", Ephesians 2:20 "with Christ Jesus Himself as the chief cornerstone", and Matthew 16:13-18 (Matthew 1st century). Simon Peter answered, "You are The Messiah, The Son of THE LIVING GOD." Jesus replied, "Blessed are you, Simon son of Jonah, for this was not revealed to you by flesh and blood, but by My FATHER in heaven. And I tell you that you are Peter, and on this rock I will build My church". Simon Peter's etymology is petrified stone, and stone has tone as sound.

However, the main etymology of stone is testimony in the ark of tabernacle (Tent of Meeting), the tablets of ten commandments, as described in Exodus 25:21, 31:18, 34:29 and 40:20-21. "HE gave him the two tablets of the covenant law, the tablets of stone inscribed by THE FINGER OF GOD". "Moses came down from Mount Sinai with the two tablets of the covenant law in his hands". "He took the tablets of the covenant law and placed them in the ark". "Then he brought the ark into the tabernacle and hung the shielding curtain and shielded the ark of the covenant law". Thus, testimony has stone, stone has ten, and stone is related to tent. 石 $\square$ stone has a stone tablet $\square$ and $\ulcorner$ tabernacle in side view.

\subsubsection{Birth's Etymology}

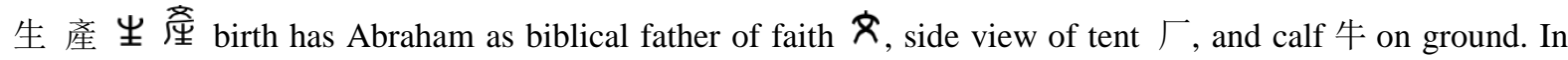
Genesis 18:1-21:7 (Moses, 2nd millennium B.C.a), "LORD appeared to Abraham near the great trees of Mamre while he was sitting at the entrance to his tent". "So Abraham hurried to the tent to Sarah." "Then he ran to the herd and selected a choice, tender calf and give it to a servant, who hurried to prepare it. He then brought some curds and milk and the calf that had been prepared". "Where is your wife Sarah?" "There, in the tent," he said. "I will surely return to you about this time next year, and Sarah your wife will have a son." "Sarah became pregnant and bore a son to Abraham in his old age, at the very time GOD had promised him”. 產 is to produce.

\subsubsection{Embryo's Etymology}

胚 embryo is boy of Abram, boy substituted with ram (ram boy), or spiritual Son as Lamb. In Genesis 17:19-22:29 (Moses, 2nd millennium B.C.a), "Sarah became pregnant and bore a son to Abraham”. “Abraham built an altar there and arranged the wood on it. He bound his son Isaac and laid him on the altar", although a ram surprisingly replaced his son. 胚 embryo is not offered on altar but substituted with offering $\boldsymbol{P}$, or offering $\boldsymbol{P}$ resulting in no other offerings, as 不 means no and - either means no or indicates divinity. In Hebrews 7:27 “Unlike the other high priests, He does not need to offer sacrifices day after day, first for his own sins, and then for the sins of the people. He sacrificed for their sins once for all when He offered Himself'.

The embryo is related to ransom as ram son, as a ram replaced Isaac son of Abraham as offering, and Son as Lamb offered Himself as ransom. 贖 ransom is to 買 buy bull $\Psi$ with wealth 貝 in Exodus 21-22. For instance, “If, however, the bull has had the habit of goring and the owner has been warned but has not kept it penned up and it kills a man or woman, the bull is to be stoned and its owner also is to be put to death. However, if payment is demanded, the owner may redeem his life by the payment of whatever is demanded. This law also applies if the bull gores a son or daughter." 
胎 embryo and placenta have $\circlearrowright$ rising cloud or smoke of fire from altar $\square$, as GOD arrived with cloud and went up from Abraham who offered burnt offering at altar. In complacency 怡, priests give 贻 burnt offering in divine ruling 治. Including both physical and spiritual descendants, Abraham's family members would increase in number to interconnect embryo, member and number.

\subsubsection{Son's Related Words}

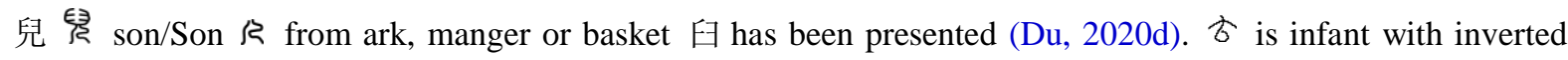
head and arms. 育充 nurture is $九$ child in flesh $\Rightarrow$ or to sacrifice flesh. When Abraham nurtured Ishmael and Issac, they must offer sacrifice on altar, and Isaac almost offered himself, as $\Rightarrow$ often means sacrificed flesh. As destiny is in test of diet set by DEITY, 養 nurture has 羊 lamb food 食, consistent with biblical clean food and Son's sacrifice as Heavenly Manna and Lamb. Grain is rain, and manna is rain 雨 in need 需 after dew 露, for manna to be rained down and look like seed to be sowed to good soil. No previous effort is necessary for the predestined arrival and sacrifice of Son and for people to accept this free grace. However, after knowing this grace, people are required by Jesus to have action. Good action is demanded by Christ's law, a necessity for eternal life. Jesus' gospel requires action by christians. In James 2:14-26 (James 1st century), "faith by itself, if it is not accompanied by action, is dead". Without action, "Even the demons believe it", and it would be demon's gospel. For instance, in Matthew 8:28-33 (Matthew 1st century), Mark 5:6-13 (Mark 1st century) and Luke 8:26-35 (Luke, 1st century), Legion believed that Jesus was Son of GOD. "What do you want with me, Jesus, Son of THE MOST HIGH GOD? I beg you". Condemn is con demon. "You see that a person is justified by what he does and not by faith alone", and "so faith without deeds is dead". Jesus and all the apostles, including Peter, James, John, Paul and others, all demand good deeds throughout new testament.

Sufficiency has sacrifice, which should be in sufficient supply. Deficiency is away from sacrifice. 充 sufficiency has son $\boldsymbol{\delta}$ for worshiper $\lambda$, when Abraham was promised with sufficient physical and spiritual descendants in Genesis 15-18 (Moses, 2nd millennium B.C.a). 足定 sufficiency is son of Abraham in side view, or Son Who washed feet 足. In John 13:1-15 (John 1st century), “Jesus knew that the time had come for Him to leave this world and go to THE FATHER. Having loved His Own who were in the world, He now showed them the full extent of His love." "He poured water into a basin and began to wash His disciples' feet". John baptized Jesus in 澈 clear water of 流沙宫 flowing Jordan river. The linguistic relevance of amniotic fluid 羊水 is Jesus' baptism as 羊 Lamb in water 水. 保 $九$ 我 protection has man $\pi$ next to Son/son $\xi$ on wood 木 of cross 十 or firewood /. In John 14:6 (John 1st century) Jesus answered, "I Am The Way and The Truth and The Life. No one comes to THE FATHER except through Me." If Son did not come to earth and sacrificed Himself two millenniums ago in universal atonement, no one in new testament would have been able to come to HEAVENLY FATHER. 保 $九$ 我 also means promise, and is for Abraham $\pi$ to cut offering in halves (semi) $\|$ in the covenant to his son $\mathcal{F}$ in Genesis 15:20 (Moses, 2nd millennium B.C.a). If Abraham did not offer his son Isaac to pass a divine test, we might not have been as abundantly blessed. 褆褋 swaddling cloth of Son is in Luke 2:7-12 (Luke 1st century). "She wrapped Him in cloths and placed Him in a manger". "This will be a sign to you: You will find a Baby wrapped in cloths and lying in a manger." 


\subsubsection{Orphan}

Orphan has ornith (bird), cherubim (holy birds) of ark that represents ark. 攻 肢 attack is to 扛 carry ark with two poles 杜, as in 1 Samuel 4:1-22 (Samuel 1st millennium B.C.) "Let us bring the ark of THE LORD's covenant from Shiloh". Although ark was brought to battlefield, they "were defeated" and ark was seized, because ark can not be secular military tool, and should have been in temple. GOD does not bless every warfare. High priest Eli's heart feared for the ark of GOD, heard the outcry when "the army has suffered heavy losses. Also your two sons, Hophni and Phinehas, are dead", fell backward off his chair, and broke neck. "His daughter-in-law, the wife of Phinehas, was pregnant and near the time of delivery. When she heard the news about the ark of GOD and her father-in-law and her husband, "she went into labor and gave birth, but was overcome by her labor pains. As she was dying, the women attending her said, "Don't despair; you have given birth to a son."” She named the boy Ichabod, saying, "The Glory has departed from Israel", so that orphan also has an/nor honor, no honor, or honor (honar) to depart/separate (phar). Pharmacy is separation outside of camp in Leviticus 13:5-46 (Moses, 2nd millennium B.C.a)—old testament quarantine.

\subsubsection{Son in Law}

婿落 represents either husband or son in law, because Abraham's son offering $\mathcal{P}$ and became son in law of woman 女 Rebekah's parents. In Genesis 24:12-25:26 (Moses, 2nd millennium B.C.a), "Rebekah came out with her jar on her shoulder. She was the daughter of Bethuel son of Milcah". "Isaac brought her into the tent of his mother Sarah, and he married Rebekah".

To Sarah's mother, Abraham was son in law, who offered his son $\mathbb{P}$ Isaac in flesh $\boldsymbol{P}$. In Genesis 11-22, "Sacrifice him there as a burnt offering on one of the mountains I will tell you about". "Abraham built an altar there and arranged the wood on it. He bound his son Issac and laid him on the altar". "Now I know that you fear GOD, because you have not withheld from ME your son". "Abraham looked up and there in a thicket he saw a ram caught by its horns. He went over and took the ram and sacrificed it as a burnt offering instead of his son." Test is to set altar.

\subsubsection{Daughter}

\subsubsection{The Etymology of Girl}

妞 girl has no offering by hand for 女 woman in delivery, since the unclean period for daughter's birth is twice longer, $7+7+33+33$ days. $叉$ is hand and no is /. In Leviticus 12:4-5 (Moses 2nd millennium B.C.c), "She must not touch anything sacred or go to the sanctuary until the days of her purification are over. If she gives birth to a daughter, for two weeks the woman will be unclean, as during her period. Then she must wait sixty-six days to be purified from her bleeding." This is a typical word of divine creation, as no human would create the word girl to be 丑 (叉) ugly woman 女. Although girl and ugly overlap and share biblical etymology, it was not because a girl was ugly, but because of uncleanness of the purification period, as ugly is not $(/)$ to offer offering with hand $₹$. Multilingual etymology from bible is a revolutionary conclusion in the linguistic field.

\subsubsection{Daughter}

Pharaoh's daughter adopted Moses in Exodus 2:3-10 (Moses 2nd millennium B.C.b), and daughter is to adopt, as "He was crying, and she felt sorry for him." "When the child grew older, she took him to Pharaoh's daughter and 
he became her son. She named him Moses, saying, "I drew him out of the water."' Thus, daughter could also be to draw human (from) water by Pharaoh's daughter, to draw water by Rebekah, or spring water given to daughter in Judges 1:12-15 (Unknown 1st millennium B.C.b), as semantic match between warranty and guaranty indicates that in some cases gua/aug could substitute with war/raw. Guard is ward, guardian is warden, and warn and wary are caution. 生 raw has taurus 牛.

戰 war has worshiping altar with grating 田, as Hebrews carried altar in their march and holy wars. “THE LORD's divisions left Egypt. Because THE LORD kept vigil that night to bring them out of Egypt, on this night all the Israelites are to keep vigil to honor THE LORD”. However, in new testament, preemptive wars are only brought in by human beings, because law of love is the strictly fundamental requirement. In Matthew 6:18-44 (Matthew 1st century) and Luke 6:27-36 (Luke 1st century), "You have heard that it was said, 'Eye for eye, and tooth for tooth.' But I tell you, do not” retaliate. "Love your enemies”. In John 15:17 (John 1st century), Jesus Christ requires that "This is My command: Love each other." However, because of religious conflicts and earthly temptations and desires, Jesus foresaw wars as inevitable before the big and dreadful day. Such wars are warning signs of failure in love.

Aught refers to any raw offering, 增 augment is to increase sacred meat, inauguration is consecration ceremony for priests near altar, augur was priest cutting offering for august purpose, and auction is to cut offering. Increase is sacred sarco (flesh), as sacrifice should be added on altar and not cease, and creatures were also "fruitful and increase in number". In Leviticus 7:15 (Moses 2nd millennium B.C.c), "The meat of their fellowship offering of thanksgiving must be eaten on the day it is offered". Carnivore is to eat fresh. Carnival is festival involving eating offered meat. Sarco is from Latin and Greek sark or sarx that represents flesh in words such as sarcomere.

\subsubsection{Daughter in Law}

The etymology of 媳 daughter in law has been presented to include woman 女, 心 heart and 自 own, as Abraham told his servant to "go to my country and my own relatives and get a wife for my son Isaac" (Du, 2019b; Moses, 2nd millennium B.C.a). To get a wife from self's clan and relatives, bride is related to tribe, 娶 to marry is to get 取, and 嫁 to be married has family 家. 婚 to marry has woman, clan 氏 and altar with ledge 日, in addition to its alternative biblical etymology in the wedding evening (Section 3.3. Clan). 婦, woman that sometimes represents wife to arrive 歸 to marry, has veil 巾, tent $\square$, and the affixes of relocation 追 and movement $\forall$, because the returning bride Rebekah took veil to cover herself (3.7.10.2. Etymology of bride and bridegroom). In other words, arrival and marriage are related words.

媳 can also represent wife and has rest 息, as the wife of Adam was created when “GOD caused the man to fall into a deep sleep; and while he was sleeping, HE took one of the man's ribs and then closed up the place with flesh. Then THE LORD GOD made a woman from the rib” in Genesis 2:7-22 (Moses, 2nd millennium B.C.a). 息 also means breath, as "GOD formed a man from the dust of the ground and breathed into his nostrils the breath of life". In bilingual match，鼻 nose has own 自，息 breath has rest 息, and 休 rest has tree 木 after “GOD made all kinds of trees" there. To respire in respiration is related to rest and tree, as tre/ret can sometimes represent tree as a root.

息 nap has nasal 鼻's affix sinus 自 (na/nat/nas/nis), which is also in natal, native and nature 自然, because of native Adam's nostrils. "GOD formed the man from the dust of the ground and breathed into his nostrils the breath 
of life, and the man became a living being." Clan is natal, and natal is nasal. Innate, prenatal, postnatal, nation, national, international and nationality are derived words. The affix sin/nis of nose is in words such as sinusitis, snout as creatures' nose, scent and snivel by nose, and snuff and sniff. 自 means self and own. In the past millenniums, linguists hypothesized that nose represented self because people pointed to their own nose when introducing each other (Liu, 2017), although nose's true etymology is Genesis 2:7 (Moses, 2nd millennium B.C.a) creation-a typical example how languages were confused around Babel tower. 自 also means since in bilingual match.

The affixes selves and self have "flesh of my flesh" Eve as the definitive etymology from Genesis 2:23 (Moses, 2nd millennium B.C.a). The man said, "This is now bone of my bones and flesh of my flesh; she shall be called 'woman,' for she was taken out of man.” This precisely explains why self is singular but selves is plural, as selves has the name of Eve (eve), so that there were two humans rather than only Adam himself within the garden. Plural is related to help as in Genesis 2:18 (Moses, 2nd millennium B.C.a), "I will make a helper suitable for him". In bilingual match, flesh has self. 自 self is related to flesh 身. 嗅 olfactory or smell has the nasal affix related to self 自, related to stink 臭 containing sin/nas/nis. Olfactory's olf is elf, similar to the relationship between blow and blew as two tenses.

\subsubsection{Nephew}

\subsubsection{Nephew as Brother's Son}

Lot was nephew of Abraham, and Ishmael was nephew of Sarah. 侄, nephew as brother's son, has man 人 to go to 至, as in Genesis 11:31-12:5 (Moses, 2nd millennium B.C.a) Abram “took his wife Sarai, his nephew Lot, all the possessions they had accumulated and the people they had acquired in Haran, and they set out for the land of Canaan, and they arrived there.” In Genesis 21:8-20 (Moses, 2nd millennium B.C.a), Sarah drove off her nephew Ishmael and Hagar who "wandered in the desert of Beersheba" and lived "in the desert of Paran". Lot is not few, not is ne, and few is phew coincidentally, although the true etymology of nephew is for human to come (pe-) to new place. Esau was nephew 侄 of Ishmael, as 至 represents arrow's arrival and to reach is from archer. In Genesis 28:6-9 (Moses, 2nd millennium B.C.a), "Esau learned that Isaac had blessed Jacob and had sent him to Paddan Aram to take a wife". "So he went to Ishmael and married Mahalath, the sister of Nebaioth and daughter of Ishmael".

\subsubsection{Nephew as Sister's Son}

甥, nephew as sister's son, is 生 birth of male 男, not female, as in Genesis 19 (Moses, 2nd millennium B.C.a) "they got their father to drink wine" and "both of Lot's daughters became pregnant by their father. The older daughter had a son, and she named him Moab; he is the father of the Moabites of today. The younger daughter also had a son". These two sons are nephews of their aunts, and nephew has wene of wine. Reuben, Simeon, Levi and Judah were among the nephews of Rachel. In Genesis 29:16-35:18 (Moses, 2nd millennium B.C.a) "Laban had two daughters; the name of the older was Leah, and the name of the younger was Rachel." "Leah became pregnant and gave birth to a son. She named him Reuben, for she said, "It is because the LORD has seen my misery. Surely my husband will love me now." She conceived again, and when she gave birth to a son she said, "Because the LORD heard that I am not loved, HE gave me this one too." So she named him Simeon. Again she conceived, and when she gave birth to a son she said, "Now at last my husband will become attached to me, because I have borne him three sons." So he was named Levi. She conceived again, and when she gave birth to a son she said, "This time I will praise the LORD." So she named him Judah." Rachel and her maidservant gave birth to two biological sons and two 
adopted sons, no female. "Here is Bilhah, my servant. Sleep with her so that she can bear children for me and I too can build a family through her" and "she named him Dan. Rachel's servant Bilhah conceived again and bore Jacob a second son" before "she named him Naphtali". "She named him Joseph, and said, "May THE LORD add to me another son."" "She named her son Ben-Oni. But his father named him Benjamin."

\subsubsection{Niece}

Related in etymology to nice 佳 for man 人 to go from one land 土 to another land 土, niece is to a nearby residence to see neighbor, as in Genesis 27-34 (Moses, 2nd millennium B.C.a) "Dinah, the daughter Leah had borne to Jacob, went out to visit the women of the land. When Shechem son of Hamor the Hivite, the ruler of that area, saw her, he took her and violated her. His heart was drawn to Dinah”. 㚣/奸 rape has chaperoning women 女 to visit land 土, as Dinah visited the women of neighbor's land. 侄女 niece has arrival 至里 as Dinah went to Shechem. Linguists were puzzled by why rape was among women as 㚣 has three women, but Dinah and her visited women solve this riddle. This is also why rape is related to chaperone as peer. Niece is Dinah as niece of Esau and Rachel. For Jacob, "my brother Esau is a hairy man". For Rachel, "Now Laban had two daughters; the name of the older was Leah, and the name of the younger was Rachel."

To deceive has iece of niece, as Jacob's sons were in fury and responded to Shechem's proposal "Get me this girl as my wife" "on one condition only: that you become like us by circumcising all your males". So "every male in the city was circumcised". "Three days later, while all of them were still in pain, two of Jacob's sons, Simeon and Levi, Dinah's brothers, took their swords and attacked the unsuspecting city, killing every male" including Hamor and Shechem. 害 to harm links to circumcision 割, as Shechem raped Dinah, causing deceitful retaliating attack, although Jacob did not favor this attack in Genesis 34:30 and 49:5 (Moses, 2nd millennium B.C.a). "Simeon and Levi are brothers - their swords are weapons of violence. Let me not enter their council, let me not join their assembly, for they have killed men in their anger and hamstrung oxen as they pleased". Violence is ne love, no love.

Harm links to Hamor and Hebrews' arms, and calamity has city male - the best indication that circumcision is harmful to natural survival. Israelites have been against natural selection to keep this tradition for thousands of years, but GOD gave Israel the land of Shechem in surprise. All parents love their children, but Hebrews wound every boy on the eighth day of birth by pain, bleeding, infection and military drawback. The answer is extremely logical: circumcision is the physical sign and covenant from GOD with the chosen testifying nation.

\subsubsection{Grandson}

孫嗦 grandson has to 系 tie son 子 with thread 条, as in Genesis 38:27-30 (Moses, 2nd millennium B.C.a) Israel’s grandson Zerah "had the scarlet thread on his wrist" $\pi$. 遜, yield in position or right to another person, has Abraham's grandson 孫, as Zerah yielded to his brother Perez to be born later.

\subsection{Language Teaching and Learning Via Biblical Etymology and Bilingual Mutual Match}

Because ancient words were created to multilingually mutually match biblical etymology, the method of language teaching and leaning will certainly reflect this. In native vocabulary teaching, "word"s etymology is instructed as interesting biblical story. Then, learners are taught how substructures of this word are organized to match this biblical story. For example, when teaching breath 息, teacher tells students that 息 is related to Adam's 
nose 鼻, because GOD "breathed into his nostrils the breath of life" in Genesis.

In foreign vocabulary learning, a teacher further tells students how a word in the students' native language biblically matches its translation in the other language to be learned. For examples, when English speakers learn 悟 in the language of China, the teacher should tell the learners that 悟 know contains own 吾 because of Abraham.

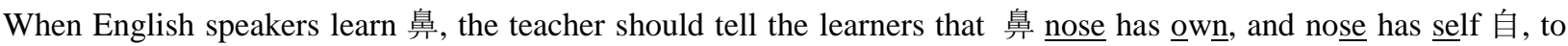
improve understanding and memory of these words. Such revolutionary method of acquiring vocabulary should be the future direction of language teaching and research.

\section{Discussion}

\subsection{Multilingual Mutual Match in Biblical Etymology}

In etymology, patriotism is parental worship to HOLY FATHER. Patriot has to cut in pair at altar. The etymology of relatives is related to altar, as biblical relatives worship around altar. The etymology of family is related to flame due to burnt offering at altar. Multiple languages exhibit identical biblical etymology for one of the most frequently cited words, parent. Parent is to cut offering in pair, like the father of Ishmael and Isaac did in Genesis 15:10 (Moses, 2nd millennium B.C.a). “Abram brought all these to him, cut them in two and arranged the halves opposite each other”. 饼 bread is in peer and parallel 并, and biscuit is bi cut. 尚尚 culture has to cut

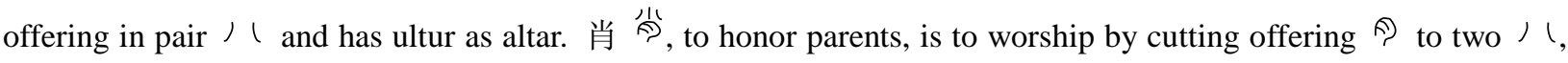
a surprising etymology to the world.

This and recent testimonies provide systematic evidence that numerous words of relatives have multilingual biblical etymology. For instance, Infant 嬰 (Jesus) is the financial treasures presented to Mary, 休 rest has tree 木, natal is nasal, woman is own, female is self in flesh, line is linen yarn, 裔 lineage is related to linen, offspring is off spring, bride is to tribe, parental nephew has new place, maternal nephew is no female, and stone is testimony of ten commandments in Tent. Thousand pages of biblical stories were written in full details with names, time, places, people and events, for instance, Beer Lahai Roi well between Kadesh and Bered. Etymological analysis gives perfect biblical match to this spring for offspring of Hagar and Ishmael.

Linguists might be perplexed by why rape was three women 姦, but Dinah and her visited women answers why rape is related to chaperone as peer. 妞 girl has no offering by hand of woman 女 in unclean period for girl's birth. 毒 粚 venom has tree 丰 and mom 母, and shares resemblance to no 布 from forbidden fruit. Such words could not have been created by human beings, as they do not fit common sense but fully match bible. These are typical words of divine creation, as no woman rapes woman, no one would create girl to be 叉丑 ugly woman 女, and no mom is venom. The biblical etymological analysis answers such mysteries in linguistic archaeology, proving the key claim in Genesis 11 (Moses, 2nd millennium B.C.a) that "THE LORD confused the language of the whole world".

Multilingual biblical etymology answers rudimentary grammar and semantic structure of language of China, English, and additional languages. For instance, selves and self have “flesh of my flesh” Eve as etymology. 如 whether is related to heat at thermal theological altar $\square$, and if is the affix of fission to cut offering, answering why in grammar whether is if. 
Many other basic bilingual words have bible as definitive etymology. For instance, 餓 hunger is from hunter and has 我 me to eat 食, as in Genesis 25:27-27:4 (Moses, 2nd millennium B.C.a) the hungry hunter "Esau came in from the open country, famished. He said to Jacob, "Quick, let me have some of that red stew! I'm famished!'” Numerous words match Esau and Jacob to form systematic logical chain, indicating that they were true persons in real historical events. Thus, multilingual biblical etymology is presented as an essential approach in linguistic and theological archaeology.

Quite a number of words related to twins Esau and Jacob are switched or refer to both. For example, 梯 stairway and younger brother 弟 have archer弓人, starve/famine 饥饿 has several 几 mine 我 in name [Jacob identified himself as Jacob, Israel and Esau, and Esau was also named Edom. In Genesis 36:1-8 (Moses, 2nd millennium B.C.a), "This is the account of the family line of Esau (that is, Edom)". "So Esau (that is, Edom) settled in the hill country of Seir]. 祝 blessing's elder brother 兄 has stone or altar 口. The divine calling could have been to either sibling, so that "the twins" rather than singular name was written by Paul to perplex many people. In Romans 9:11-14, "before the twins were born or had done anything good or bad-in order that GOD's purpose in election might stand: not by works but by HIM WHO calls—-she was told, "The older will serve the younger"”, when work was unnecessary for choosing the twin grandsons of Abraham, but righteous action is necessary for choosing one over the other twin. This is an essential conclusion for not only linguistics but also philosophy and theology, when it was predestination for GOD to select between the twins, but only started to call Jacob after Jacob fled away when Esau threatened to kill Jacob. "The older" could be either Esau or Jacob dependent on time of fertilization (genetically dizygotic based on red hairy skin versus smooth skin), birth or switched birthright, and GOD did not specify either one to Rebekah. When GOD talked about "Jacob I loved, but Esau I hated", it had been centuries after Esau and Jacob's departure, so that Paul could cite Malachi 1:2-3 on why gentle Jacob but not death-threatening Esau was favored. This is why Paul claimed, "Is GOD unjust? Not at all!" In Galatians 2:6, "GOD does not show favoritism". If Esau cared more about birthright when the firstborn could be offered to GOD, congratulated greater blessing to his brother to wish Jacob the best, and did not threaten to kill to break the everlasting covenant through his ancestor Noah, GOD might have called Esau, and Esau could have had an additional name called Israel. In consistence, the etymological analysis indicates that a set of words can be allocated to either twin. Thus, etymological evidence strengthens biblical interpretation. GOD credited Abraham because of his righteous action accompanied with faith, as why faith and action is strictly required in James 3:17-26 (James 1st century), when apostle James talked about the faith to GOD by fully faithfully reiterating Jesus Christ's instruction on true faith and the accompanied actions as belief in heart rather than demon's belief. Nevertheless, words were already created before Moses wrote the initial bible. Thus, etymological analysis proves divine creation and predestination for divine arrangement of Abraham's twin grandsons.

Languages of China and English were created before biblical writing by Moses or apostles or christianity. Thus, both languages must have been divinely created ahead of time to match bible and astonishingly, each other. For instance, the known affix of motion and location, 追 and $₹$ of 陵, perfectly matches mobility and motion of tomb in bilingual biblical way, a hallmark of systematic creation of words from IDENTICAL WISDOM.

That a lot of derived languages were made by mankind does not mean that initial languages were also made by mankind, in analogy to that parents have children does not mean that the first generation was also born naturally. No human parents were monkeys. By random sampling, all analyzed words match bible in etymology without exception. 
Such an astonishing matching rate not only indicates that words were created divinely, but also gives a new way in language study to judge whether a word is native or introduced from other languages, because all the native words should reflect biblical etymology. If some words cannot be biblically decoded, these words are likely introduced by phonetic conversion from other accents. This is especially necessary for languages like English, when many words were absorbed into this language.

In the past, people thought that 驽 bow was created phonetically by borrowing 奴's sound. Such traditional hypothesis on semantic origin that dominated the linguistic field has to be revised, as words were created to match both meaning and sound: 驽 bow has servant 奴 because the archer Ishmael was son of a maidservant. Warrior has arrow, consistent with the definitive conclusion that every native word matches not only sound but also meaning. We all know if we keep the sound, then it may not keep the meaning; if we preserve the meaning, then it may not keep the sound. The best example is the Pinyin pronunciation system of the language of China. For instance, Sanxingdui cultural reserve actually means triaster heap. It is impossible for all the words to be created to fit both sound and meaning if they were created by mankind, but so far we have found that all the analyzed native words express both biblical meaning and pronunciation. This phenomenon is consistent with co-emergence of ancient written languages with their spoken versions by divine creation, as otherwise it is impossible to systematically keep both sound and meaning. For the first time in history, systematic evidence is presented to reinforce the amazing conclusion that ancient words were divinely created in full meaning to predestinedly match the historical bible as their etymology. Multilingual mutual match in biblical etymology confidently proves that ancient languages had to be provided by GOD. This is the origin of language.

\subsection{Teaching and Research via Multilingual Mutual Match in Biblical Etymology}

Biblical etymology will greatly facilitate children to remember words, since there are interesting biblical stories behind all the words as the origin of their meaning and structure. It will also greatly enhance the ability of people to acquire a second language, because bilingual mutual match in biblical etymology makes it much easier to understand and memorize words and their translation in the other language. Mutual multilingual match to biblical etymology is a revolutionary discovery, and will dramatically improve not only the method of acquiring languages but also the understanding of our divine origin as well as lexicon's origin in linguistic archaeology.

\section{Conclusion}

For the first time in history, this article presents systematic evidence for biblical etymology of all relatives. This solves millenniums of word riddles on relatives, and presents definitive evidence that the etymology of relatives is biblical. Multilingual mutual match in etymology from bible is a revolutionary conclusion, with great impact on our culture, language acquisition, education and eternal life. This major discovery in civilization that bible is the definitive dictionary of etymology for ancient languages not only provides linguistic evidence embedded in every word for the historical scroll, but also should dramatically enhance teaching and learning of vocabulary in the language of China and English and all the additional languages worldwide.

\section{Acknowledgement}

We are grateful to GOD THE CREATOR with full gratitude in the highest respect. 


\section{References}

Campbell, L., Kaufman, T. and Smith-Stark, T. C. (1986). Meso-America as a linguistic area. Language, 62(3): 530-70. Available: https://doi.org/10.1353/lan.1986.0105

DeFrancis, J. (1984). The chinese language-Fact and Fantasy. ISBN: 0-8248-1068-6 / 0-8284-0866-5.

Du, J. X. (2019a). Bilingual dissection of words with biblical correlation. International Journal of Language and Linguistics, 7(1): 50-54. Available: https://doi.org/10.11648/j.ijl1.20190701.17

Du, J. X. (2019b). Bilingual match to biblical flood. International Journal of Linguistics, 11(1): 196-216. Available: https://doi.org/10.5296/ijl.v11i1.14434

Du, J. X. (2019c). Seven days, numbers and heavenly stems. International Journal of Linguistics, 11(2): 107-51. Available: https://doi.org/10.5296/ijl.v11i2.14755

Du, J. X. (2020a). Biblical etymology of prophet and priest. English Literature and Language Review, 6(4): 54-63. Available: https://doi.org/10.32861/ellr.64.54.63

Du, J. X. (2020b). Biblical etymology of tabernacle and altar. International Journal of Linguistics, 12(3): 9-27. Available: https://doi.org/10.5296/ijl.v12i3.17012

Du, J. X. (2020c). Biblical etymology of organs and body parts. English Literature and Language Review, 6(5): 69-90. Available: https://doi.org/10.32861/ellr.65.69.91

Du, J. X. (2020d). Bilingual biblical etymology - origin of language. International Journal of Linguistics, 12(5): 30-94. Available: https://doi.org/10.5296/ijl.v12i5.17716

Du, J. X. (2020e). Biblical etymology of earthly branches and jesus christ. SocArXiv: Available: https://doi.org/10.31235/osf.io/r9mdz

Du, J. X. (2020f). Creation of additional ancestors. LawArXiv. 10.31228/osf.io/tqwsc.

James (1st century). James.

John (1st century). John.

Joshua (2nd millennium B.C.). Joshua.

Liu, S. H. (2017). 白鱼解字.. ISBN-10 7513326843. ISBN-13 978-7513

Luke (1st century). Luke.

Mark (1st century). Mark.

Matthew (1st century). Matthew.

Moses (2nd millennium B.C.a). Genesis.

Moses (2nd millennium B.C.b). Exodus.

Moses (2nd millennium B.C.c). Leviticus.

Moses (2nd millennium B.C.d). Numbers.

Moses (2nd millennium B.C.e) Deuteronomy.

Samuel (1st millennium B.C.). 1 Samuel.

Sima, Q. (1st century B.C.). Records of the historian.

Unknown author, (1st millennium B.C.a) 1 kings.

Unknown, author. (1st millennium B.C.b). Judges.

$\mathrm{Xu}$, S. (100-121 A.D.). Analytical dictionary of characters. 